DOI https://doi.org/10.30525/978-9934-26-025-4-9

\title{
FISHERIES USE OF THE PERSHOTRAVENSKE RESERVOIR (UKRAINE)
}

\section{Marenkov O. M., Izhboldina O. O.}

\section{INTRODUCTION}

Pershotravenske Reservoir (Dnipropetrovsk Region, Verkhnyodniprovsk District, Samotkan Village) was created in the lower course of the Samotkan River, a right-bank first-order tributary of the Dnipro River (within the Kamyanske Reservoir) in 1960-1963 to regulate river flow and prevent floods, as well as flooding of adjacent areas. The primary user is the Kamyansk Regional Department of Water Resources. The Samotkan river was used for the transit of the industrial wastewater from the system of storage reservoirs of the Vilnohirsk Mining and Processing Plant to the Dnipro river in the water area of the lower part of the Kamyansky Reservoir). Thus, Pershotravenske Reservoir is a significantly transformed water ecosystem, which is influenced by negative anthropogenic factors.

Given the current economic situation in Ukraine and, in particular, in Prydniprovya, the concept of multipurpose utilization of reservoirs for fishculture (both for obtaining quality fish products and for organizing recreation) is significantly advantageous. The reason for this is the distinct possibility of creating a balanced industrial load along with preserving the original (aboriginal) ichthyocomplex and, at the same time, maintaining the natural level of biological diversity of aquatic ecosystems in small rivers of the region. From this perspective, the Pershotravenske Reservoir, which area is relatively large for reservoirs on small rivers of the Dnipropetrovsk region (it reaches 150.4 hectares), is certainly one of the most promising reservoirs.

\section{General characteristics of the reservoir}

Pershotravenske Reservoir ( $48^{0} 58^{\prime} 83^{\prime \prime}$ N. $34^{0} 27^{\prime} 39^{\prime \prime} \mathrm{E}$.) is located in the north-western part of the Dnipropetrovsk region, $10 \mathrm{~km}$. from the mouth of the Samotkan River. Administratively, it is located in the Verkhnyodniprovsk district of the Dnipropetrovsk region, within the Pershotravensk village council. Water supply partly involves the accumulation of floodwaters from the catchment area of the Samotkan River basin, and mainly consists of the inflow of water masses through the system of higher channel ponds and reservoirs of the Vilnohirsk Mining and Metallurgical Complex (VMMC). The reservoir has a typical elongated 
shape, extending from northeast to southwest. The greatest length is $1.2 \mathrm{~km}$, width is $600 \mathrm{~m}$, maximum depths are up to $4 \mathrm{~m}$, and average depths are $3.0 \mathrm{~m}$ (table 1).

Table 1

\section{The main morphometric characteristics} of the Pershotravenske Reservoir

\begin{tabular}{|c|c|c|c|c|c|c|}
\hline \multirow{2}{*}{$\begin{array}{c}\text { Volume, } \\
\text { thousand } \mathbf{~ m}^{\mathbf{3}}\end{array}$} & \multicolumn{2}{|c|}{ Depth, $\mathbf{m}$} & \multicolumn{2}{c|}{ Width, $\mathbf{~ k m}$} & Length, & \multirow{2}{*}{ Area, ha } \\
\cline { 2 - 5 } & average & max. & average & max. & $\mathbf{k m}$ & \\
\hline 3000 & 3.0 & 4.0 & 0.3 & 0.5 & 1.2 & 150.4 \\
\hline
\end{tabular}

The basis for the research at the Pershotravenske Reservoir is the Law of Ukraine "About fishery, industrial fishery and protection of water bioresources"1, the Law of Ukraine "On Fauna" dated 13.12.2001 No. 2894-III, Art. $37^{2}$, the requirements of the "Instruction about the procedure of artificial cultivation, cultivation of fish, other water live resources and their uses in special commodity fisheries" ${ }^{3}$ and permission for special use of aquatic bioresources (No. 000025/2019 dated October 2, 2019). The research was carried out with consideration for modern hydrochemical, hydrobiological, and radioecological characteristics of the reservoir, the state of its aboriginal ichthyofauna, and the invasive fish species.

The research was conducted under the current hydrobiological and ichthyologic methods ${ }^{456}$. Modern recommendations on the utilization of small reservoirs for fish-culture and other sources related to the rational use

1 Про рибне господарство, промислове рибальство та охорону водних біоресурсів : Закон України № 3677-VI. Відомості Верховної Ради України. 2012. № 17. Ст. 155.

${ }^{2}$ Про тваринний світ : Закон України № 2894-III. Ст. 37. Відомості Верховної Ради (ВВР). 2002. № 14. Ст. 97.

${ }^{3}$ Інструкція про порядок здійснення штучного розведення, вирощування риби, інших водних живих ресурсів та їх використання в спеціальних товарних рибних господарствах : Наказ Державного комітету рибного господарства України від 15 січня 2008 р. № 4.

${ }^{4}$ Озінковська С.П., Єрко В.М., Коханова Г.Д., Тарасова О.М., Полторацька В.І. Методика збору і обробки іхтіологічних і гідробіологічних матеріалів 3 метою визначення лімітів промислового вилучення риб з великих водосховищ і лиманів України. Київ : ІРГ УААН, 1998. 47 с.

5 Методические рекомендации по сбору и обработке материалов при гидробиологических исследованиях. Зоопланктон и его продукция. Ленинград : ЗИН, 1984. 35 с.

6 Методи гідроекологічних досліджень поверхневих вод / за ред. В.Д. Романенко. Київ, 2006. 628 с. 
of aquatic bioresources of Ukraine were also applied during the samples collection and processing ${ }^{7,8,9,10}$.

\section{Hydrochemical regime of the Pershotravenske Reservoir}

In 2019, along with other hydrobiological and ichthyological studies, the chemical composition and quality of water of the Pershotravenske Reservoir were estimated to determine the compliance of water characteristics with the requirements for an efficient fishery process.

The main indicators of chemical composition and properties of water, which determine the biological productivity and breeding conditions were specified: $\mathrm{pH}$, the content of dissolved gases $\left(\mathrm{O}_{2}, \mathrm{CO}_{2}\right)$, organic substances (permanganate oxidation - $\mathrm{PO}$, biological oxygen demand $-\mathrm{BOD}_{5}$ ), the content of biogenic elements $\left(\mathrm{NH}_{4}+, \mathrm{NO}_{2}^{-}, \mathrm{O}_{3}^{-}, \mathrm{PO}_{4}^{3-}, \mathrm{Fe}\right.$ total), as well as total mineralization and hardness, the concentration of major ions $\left(\mathrm{Cl}^{-}, \mathrm{SO}_{4} 2^{-}, \mathrm{Ca}^{2+}, \mathrm{Mg}^{2+}, \mathrm{Na}^{+}, \mathrm{K}^{+}\right)$. Hydrochemical analyzes were performed according to standard modern methods and with the use of the hydrochemical device EZODO AZ-86031 (Oximeter/pH-meter/conductometer/salinometer) and a set of rapid tests TESTLAB (JBL, Germany) for quick determination of water quality. Water quality was assessed following the standards for fishery reservoirs.

By the chemical composition, the reservoir water belonged to the sulfate class, calcium group. The average mineralization is $1102.1-1692.3 \mathrm{mg} / \mathrm{l}$. The condition is slightly alkaline; the active reaction $(\mathrm{pH})$ is $7.8-8.2$. The content of organic substances is slightly increased and reaches $9-14 \mathrm{mg} / \mathrm{l}$. The total content of mineral nitrogen is $1.8 \mathrm{mgN} / \mathrm{l}$, the content of phosphorus is $0.43 \mathrm{mgP} / \mathrm{l}$, which is completely sufficient for the development of producers. The content of other substances also does not exceed the limits of fishery standards (OST 15.372-87).

The content of sulfates is $690.4 \mathrm{mg} / \mathrm{l}$, chlorides $-162.1 \mathrm{mg} / \mathrm{l}$, magnesium ions $-114.0 \mathrm{mg} / \mathrm{l}$, sodium ions $-210.0 \mathrm{mg} / \mathrm{l}$, total mineralization is $1102.1-$ $1692.3 \mathrm{mg} / \mathrm{l}$, permanganate oxidation is $10-20.1 \mathrm{mgO} / \mathrm{l}$, ammonium nitrogen content reaches $0.173 \mathrm{mg} / \mathrm{l}$, and total iron is $0.05 \mathrm{mg} / \mathrm{l}$.

The gas regime of the reservoir is generally favourable for aquatic organisms. The content of dissolved oxygen in the water during the summer was $6.8-7.6 \mathrm{mg} / \mathrm{l}$, the content of carbon dioxide was $4.5-6.5 \mathrm{mg} / \mathrm{l}$. The

7 Щербак В.I. Методи досліджень фітопланктону. Методичні основи гідробіологічних досліджень водних екосистем. Київ, 2002. С. 41-48.

8 Гринь В.Г. Об'ємно-вагова характеристика провідних видів фітопланктону Нижнього Дніпра. Питання екології $i$ ценології водних організмів Дніпра (АН УССР). Київ, 1963. С. 35-40.

9 Жадин В.И. Методика изучения донной фауны водоемов и экология донных беспозвоночных. Жизнь пресных вод СССР. Москва : Наука, 1956. Т. 4. Ч. 1. С. 279-382.

${ }^{10}$ Гринжевський М.В. Аквакультура України. Львів, 1999. С. 202. 
events of suffocation were not observed. From this perspective, the water of the Pershotravenske Reservoir meets the requirements for fishery water bodies by the main hydrochemical indicators and is suitable for growing the main aquaculture objects of Ukraine ${ }^{11213}$.

\section{State of the hydrobiocenosis components of the Pershotravenske Reservoir}

Aquatic plants. Groups of aquatic plants of the Pershotravenske Reservoir are represented by associations of submerged and air-water plants typical of small rivers in the region. Currently, air-water plants partially occupy moistened coasts, while the main area is in the upper reaches in the littoral of the reservoir.

Groups of submerged aquatic plants are highly developed and have typical features. In all types of biotopes, dominants are fennel-leaved pondweed (Potamogetonetum pectinati), curly-leaved pondweed (Potamogetonetum crispi), and morass-weed (Ceratophylletum demersi). In the overwater layer, there are ivy-leaved duckweed (Lemna trisulca L) and little duckweed (Lemna minor L.). The degree of overgrowth during the maximum growing season reached $30 \%$, which averaged to 50 hectares. The littoral is dominated by plant groups of air-water plants represented by common reed (Phragmites australis Cav. Trin. Oh, Steud.), lakeshore bulrush (Schoenoplectus lacustris L.), greater pond sedge (C. riparia Curt.) with scattered representatives of curled sorrel (Rumex crispus L.). Intermittent groups are formed in the upper reaches, separated by open water areas. On the main water area, they are located in a ribbon-like coastal strip with an average width of $2-10 \mathrm{~m}$. The total area of overgrowth is up to $10 \%$, which on average is up to 14.3 hectares.

Submerged aquatic plants also have typical features. All types of biotopes are dominated by fennel-leaved pondweed (Potamogetonetum pectinati), curly-leaved pondweed (Potamogetonetum crispi), morass-weed (Ceratophylletum demersi). In the overwater layer, there are ivy-leaved duckweed (Lemna trisulca L) and little duckweed (Lemna minor L.).

Generally, the area occupied by groups of submerged plants during the maximum growing season reaches up to $30 \%$ of the water area, that is, about 50

${ }^{11}$ Baker J.P., Olem H., Creager C.S., Marcus M.D., Parkhurst B.R. Fish and Fisheries Management in Lakes and Reservoirs, EPA 841-R-93-002, Terrene Institute and US Environmental Protection Agency. Washington, DC, USA, 1993.

${ }^{12}$ Avakyan A.B., Iakovleva V.B. Status of Global Reservoirs: the Position in the Late Twentieth Century. Lakes and Reservoirs: Research and Management. 1998. Vol. 3. P. 45-52.

13 Шерман И.М. Экология и технология рыбоводства в малых водохранилищах. Киев : Высшая школа, 1992. 213 с. 
hectares. Aquatic plants: submerged aquatic plants $-1250 \mathrm{~g} / \mathrm{m}^{2}$; air-water plants $-6800 \mathrm{~g} / \mathrm{m}^{2}$. The average phytomass of submerged plants is $1250 \mathrm{~g} / \mathrm{m}^{2}$ in raw mass. The average phytomass of air-water plants is $6800 \mathrm{~g} / \mathrm{m}^{2}$.

The production of aquatic plants corresponds to their maximum biomass (determined during the "blooming" period), increased by $10 \%$, i.e. the production to biomass ratio of aquatic vegetation $(\mathrm{P} / \mathrm{B})$ is 1.1 .

The production of submerged plants in the reservoir is:

$$
A s p=B s p \cdot \frac{P}{B s p} \cdot 10000 \mathcal{M}^{2}
$$

where Asp is the value of submerged plants production during the growing season, $\mathrm{kg} / \mathrm{ha}$; Bsp is the biomass of submerged plants, $\mathrm{g} / \mathrm{m}^{2} ; \mathrm{P} / \mathrm{Bsp}$ is the production to biomass ratio (1.1).

Asp $=1250 \mathrm{~g} / \mathrm{m}^{2} \times 1.1 \times 10000 \mathrm{~m}^{2}=13750000 \mathrm{~g} / \mathrm{ha}=13750 \mathrm{~kg} / \mathrm{ha}$.

Similarly, the production of air-water plants is determined:

Aap $=6800 \mathrm{~g} / \mathrm{m}^{2} \times 1.1 \times 10000 \mathrm{~m}^{2}=74800000 \mathrm{~g} / \mathrm{ha}=74800 \mathrm{~kg} / \mathrm{ha}$.

Consequently, the annual production of aquatic plants of the reservoir consists of products of submerged plants $(13750.0 \mathrm{~kg} / \mathrm{ha} \times 50 \mathrm{ha})$, that is, 687.5 tons and products of air-water plants (71 $500 \mathrm{~kg} / \mathrm{ha}$ x $14 \mathrm{ha}), 1047$ tons.

Generally, given the indicators of aquatic plants biomass, this reservoir belongs to the class I of the fisheries classification of the steppe zone of Ukraine. Whereas the reservoir functions as part of a natural hydrographic network, through the lens of ecology, it is meaningful to load hydrophytocenoses not only to obtain maximum volumes of fish products but also to maintain the balance of the reservoir ecosystem.

Phytoplankton. Phytoplankton of the reservoir is formed through the agricultural complex typical of small reservoirs of the Southern steppe of Ukraine. The dominant position in summer was occupied by blue-green algae (the main forms are Microcystis, Anabaena, Spirulina) and green algae (Chlorella). The diatoms (Navicula) developed to a lesser extent.

Phytoplankton of the Pershotravensk Reservoir was represented by the seven systematic groups: blue-green algae, euglenes, volvox, pyrophytes, desmids, protococcus, diatoms. A total of 40 algae taxa were recorded. The largest number of species was found in the pelagic part of the reservoir. The dominant forms were representatives of Scenedesmus: Scenedesmus acuminatus (Lagerh.) Chod, Sc. quadricauda (Turg) Breb., Sc. obliguus; of euglenes: Euglena viridis, E. Acus, E. charkowiensis; and of diatoms: Navicula sp., Pinnularia sp. There were no significant changes in the structure of phytoplankton compared to previous data.

The maximum number and biomass of algal flora are registered in the littoral of the reservoir. The significant number and biomass of 
phytoplankton in this area is a result of the most active vegetation of bluegreen and euglenic algae. The biomass of blue-green algae in littoral amounted to $28.49 \mathrm{mg} / \mathrm{l}$, the biomass of euglenes reached $12.16 \mathrm{mg} / \mathrm{l}$, while in pelagial they reached $2.19 \mathrm{mg} / \mathrm{l}$ and $8.55 \mathrm{mg} / \mathrm{l}$, respectively. At the same time, in the pelagic part of the reservoir, protococcus algae, which are valuable food for fish, developed more intensively. Their biomass was more than 2.5 times higher than that in the littoral. Relatively significant biomass, both in the coastal zone and in pelagial, was formed by diatoms, but due to their calcareous shell, they are not very significant for fish nutrition.

The average number of phytoplankton in this reservoir was 15194.5 thous.cells/l, and its biomass reached $29.5 \mathrm{mg} / \mathrm{l}$. By the quantitative development of phytoplankton, the Pershotravenske Reservoir can be ranked as medium food capacity reservoir with the transition to high food capacity one by some groups of phytoplankton during the maximum growing season (the fisheries class I). In general, despite the presence of a certain number of stocked fish species, the reservoir currently is tangibly promising for setting up the pasture fish farming.

Proceeding from the obtained data, it is possible to determine the value of primary additional phytoplankton production. For the steppe zone of Ukraine, the production and biomass coefficient of this group of organisms $(\mathrm{P} / \mathrm{B})$ is 120 , the value of the photic layer, respectively, is $1.5 \mathrm{~m}$. Since phytoplankton development occurs within the photic layer, over the entire water area of the reservoir, the calculation is made per 1 ha of the water area, and the total area of the reservoir is taken into account when calculating potential fish production.

$$
A p p=B p p \cdot \frac{P}{B p p} \cdot H l \cdot 10000 m^{2},
$$

where App is the value of phytoplankton production during the growing season, $\mathrm{kg} / \mathrm{ha}$; Bpp is the average biomass of phytoplankton, $\mathrm{g} / \mathrm{m}^{3} ; \mathrm{P} / \mathrm{Bpp}$ is the production to biomass ratio (120); $\mathrm{Hl}$ is the size of the photic layer $(1.5 \mathrm{~m})$.

$$
\text { App }=29.5 \mathrm{~g} / \mathrm{m}^{3} \times 120 \times 1.5 \mathrm{~m} \times 10000 \mathrm{~m}^{2}=53100000 \mathrm{~g} / \mathrm{ha}=53100.0 \mathrm{~kg} / \mathrm{ha} \text {. }
$$

Thus, it can be stated that the reservoir has productive opportunities for using it for fishery purposes; the indicators of phytoplankton biomass allow subsuming the reservoir under the class I of the fisheries classification of the steppe zone of Ukraine.

Zooplankton. 12 species of rotifers, 6 species of copepods and 5 species of cladocerans were revealed in the zooplankton of the reservoir. Forage zooplankton of the reservoir is formed mainly by copepods (with the forms Thermocyclops, Acanthocyclops, Eucyclops). In the total biomass, the share 
of copepods reached $84 \%$. Bosmina and Chydorus dominated among the cladocerans. Their share in the total biomass was about $5 \%$. The dominant rotifer species were representatives of the genera Asplanchna and Brachionus.

Concerning the sanitary condition and zooplankton indicators, the Pershotravensk Reservoir was characterized as moderately polluted during the research period, since mezasaprobic species accounted for 55\% among zooplankton species indicating organic pollution.

It has been found that the quantitative development of zooplankton in the reservoir at the present stage is characterized as a medium with a certain trend to low, due to the numerical dominance of an unproductive group of rotifers. This trend continues in the long-term aspect.

The average zooplankton biomass of the Pershotravenske reservoir was $1.65 \mathrm{~g} / \mathrm{m}^{3}$. The value of primary zooplankton production is determined based on biomass indicators, $\mathrm{P} / \mathrm{B}$ ratio, which for the steppe zone of Ukraine is equal to 20 and the value of the photic layer, which respectively is $1.5 \mathrm{~m}$.

$$
A z p=B z p \cdot \frac{P}{B z p} \cdot H l \cdot 10000 m^{2},
$$

where Azp is the value of zooplankton production for the growing season, $\mathrm{kg} / \mathrm{ha}$; Bzp is the average zooplankton biomass, $\mathrm{g} / \mathrm{m}^{3} ; \mathrm{P} / \mathrm{Bzp}$ is the production to biomass ratio (20); $\mathrm{Hl}$ is the size of the photic layer $(1.5 \mathrm{~m})$.

Azp $=1.65 \mathrm{~g} / \mathrm{m}^{3} \times 20 \times 1.5 \mathrm{~m} \times 10000 \mathrm{~m}^{2}=495000 \mathrm{~g} / \mathrm{ha}=495 \mathrm{~kg} / \mathrm{ha}$.

Based on the data obtained, the Pershotravenske reservoir can be subsumed under the fisheries class II by the zooplankton group.

Macrozoobenthos (bottom fauna). The bottom fauna of the reservoir included molluscs, oligochaetes, chironomid larvae and mysids. The forage zoobenthos of the reservoir is mainly represented by three species: Limnodrilus hoffmeisteri, Chironomus plumosus, Tanytarsus. A certain part of potential fish productivity was formed by oligochaetes. Among molluscs, large forms of bivalves (Unio, Anodonta), which food value is low, dominated.

The number and biomass of the bottom fauna of the reservoir consisted of the number and biomass of oligochaetes, chironomids larvae and mysids and ranged from $7.34-12.18 \mathrm{~g} / \mathrm{m}^{2}$. The development of macrozoobenthos has not significantly changed in the long-term aspect.

The primary production of zoobenthos, based on the indicators of its biomass in the reservoir of $8.4 \mathrm{~g} / \mathrm{m}^{2}$ and $\mathrm{P} / \mathrm{Bzb}$ (production to biomass ratio) for zoobenthos it is equal to 5 ), is: 


$$
A z b=B z b \cdot \frac{P}{B z b} \cdot 10000 m^{2},
$$

where $A z b$ is the value of zoobenthos production for the growing season, $\mathrm{kg} / \mathrm{ha}$; Bzb is the biomass of zoobenthos, $\mathrm{g} / \mathrm{m}^{2}$; $\mathrm{P} / \mathrm{Bzb}$ is production to biomass ratio (5).

$$
\mathrm{Azb}=8.4 \mathrm{~g} / \mathrm{m}^{2} \times 5 \times 10000 \mathrm{~m}^{2}=420000 \mathrm{~g} / \mathrm{ha}=420.0 \mathrm{~kg} / \mathrm{ha} .
$$

Thus, given the indicators of zoobenthos, the reservoir belongs to the class I of the fisheries classification of the steppe zone of Ukraine. The obtained value of the annual production of zoobenthos indicates the possibility of stocking the reservoir with benthophagous fish, primarily with carp.

\section{Ichthyofauna of the Pershotravenske Reservoir}

General state of the ichthyofauna. The formation of the reservoir's ichthyofauna is genetically related to the ichthyocenosis that existed before its creation in the Samotkan River (both upper sections and adjacent reservoirs and tributaries), as well as, indirectly, with the processes that occurred in the water area of the Dnipro River before the construction of dams. The most intensive process of reformation of the ichthyofauna occurred after the construction of the dam and the creation of Kamyanske Reservoir in 1960-1963. At the same time, retaining and anti-flood dams were constructed in the lower reaches of the Samotkan River and the Pershotravensk reservoir was created.

Before the construction of dams and in the first years after the commissioning of these reservoirs, the ichthyofauna of the river, as well as that of most other I order tributaries of the middle course of the Dnipro River, consisted of 33 species of fish (table 2). The basis was formed by bleak $27.06 \%$ of the population, roach $-24.04 \%$, monkey goby $-23.38 \%$, common dace $-7.45 \%$, bitterling $-8.3 \%$, northern pike $-5.09 \%$. Other species, including valuable ones: freshwater bream, zander, common carp, were represented from $2.3 \%$ to $6 \%$ of the total number of fish groups. The significant share of common dace is noticeable, given the fact that at the present stage it is registered in the tributaries of the region singly, by local populations. At the same time, such widespread species as European perch, rudd. Prussian carp in the period of 1960-1963 did not have significant indicators of number in the water area of the Samotkan River and adjacent tributaries and reached from $1 \%$ to $2 \%$, respectively.

Today, the ichthyofauna of the studied reservoir is formed at the expense of native species living in the water area of the Samotkan River and species introduced into the reservoir during the modern period of economic management 
(2006-2011). In the studied water area of the Pershotravenske Reservoir, 14 species of fish belonging to 5 families were identified (table 2).

Table 2

Species composition, status and distribution of ichthyofauna

Pershotravenske Reservoir

\begin{tabular}{|c|c|c|c|c|c|c|}
\hline \multirow{3}{*}{ Fish species } & \multicolumn{3}{|c|}{ Research period } & \multicolumn{3}{|c|}{ Characteristic } \\
\hline & \multirow{2}{*}{$\begin{array}{c}1953- \\
1960\end{array}$} & \multirow{2}{*}{$\begin{array}{c}2007- \\
2008\end{array}$} & \multirow[t]{2}{*}{2019} & $\begin{array}{c}\text { origin/ } \\
\text { nutrition }\end{array}$ & $\begin{array}{l}\text { resource } \\
\text { value }\end{array}$ & $\begin{array}{l}\text { distribution/ } \\
\text { number }\end{array}$ \\
\hline & & & & I & II & III \\
\hline 1 & 2 & 3 & 4 & 5 & 6 & 7 \\
\hline \multicolumn{7}{|c|}{ Cyprinidae } \\
\hline $\begin{array}{l}\text { 1. Common dace } \\
\text { Leuciscus } \\
\text { leuciscus } \\
\text { (Linnaeus, 1758) }\end{array}$ & + & - & - & N/B & RBU & MWS/MN \\
\hline $\begin{array}{l}\text { 2. Chub Squalius } \\
\text { cephalus } \\
\text { (Linnaeus, 1758) }\end{array}$ & + & - & - & $\mathrm{N} / \mathrm{E}$ & I & MWS/IN \\
\hline $\begin{array}{l}\text { 3. Ide Leuciscus } \\
\text { idus (Linnaeus, } \\
\text { 1758) }\end{array}$ & + & - & - & $\mathrm{N} / \mathrm{E}$ & I & NWS/S \\
\hline $\begin{array}{c}\text { 4. Roach Rutilus } \\
\text { rutilus (Linnaeus, } \\
1758 \text { ) }\end{array}$ & + & - & + & $\mathrm{N}(\mathrm{IN}) / \mathrm{B}$ & I & WS/MN \\
\hline $\begin{array}{l}\text { 5. Rudd Scardinius } \\
\text { erythrophthalmus } \\
\text { (Linnaeus, 1758) }\end{array}$ & + & + & + & $\mathrm{N} / \mathrm{E}$ & I & $\mathrm{WS} / \mathrm{N}$ \\
\hline $\begin{array}{l}\text { 6. Common nase } \\
\text { Chondrostoma } \\
\text { nasus (Linnaeus, } \\
1758 \text { ) }\end{array}$ & + & - & - & N/B & I & NWS/IN \\
\hline $\begin{array}{l}\text { 7. Schneider } \\
\text { Alburnoides } \\
\text { bipunctatus } \\
\text { (Bloch, 1782) }\end{array}$ & + & - & - & $\mathrm{N} / \mathrm{E}$ & NI & NWS/IN \\
\hline $\begin{array}{c}\text { 8. Bleak Alburnus } \\
\text { alburnus } \\
\text { (Linnaeus, 1758) }\end{array}$ & + & - & - & $\mathrm{N} / \mathrm{E}$ & LI & WS/MN \\
\hline $\begin{array}{c}\text { 9. Belica } \\
\text { Leucaspius } \\
\text { delineatus (Heckel, } \\
1843 \text { ) }\end{array}$ & + & + & + & $\mathrm{N} / \mathrm{ZP}$ & NI & MWS/IN \\
\hline $\begin{array}{l}\text { 10. White bream } \\
\text { Blicca bjoerkna } \\
\text { (Linnaeus, 1758) }\end{array}$ & + & & & N/B & I & WS/MN \\
\hline
\end{tabular}


Continuation of Table 2

\begin{tabular}{|c|c|c|c|c|c|c|}
\hline 1 & 2 & 3 & 4 & 5 & 6 & 7 \\
\hline $\begin{array}{c}\text { 11. Freshwater } \\
\text { bream Abramis } \\
\text { brama (Linnaeus, } \\
1758 \text { ) }\end{array}$ & + & - & + & N/B & VI & WS/MN \\
\hline $\begin{array}{c}\text { 12. White-eye } \\
\text { bream Ballerus } \\
\text { sapa (Pallas, 1814) }\end{array}$ & + & - & - & N/B & I & NWS/S \\
\hline $\begin{array}{c}\text { 13. Zope Ballerus } \\
\text { ballerus (Linnaeus, } \\
1758 \text { ) }\end{array}$ & + & - & - & N/ZP & I & NWS/S \\
\hline $\begin{array}{c}\text { 14. Asp Leuciscus } \\
\text { aspius (Linnaeus, } \\
1758 \text { ) }\end{array}$ & + & - & - & $\mathrm{N} / \mathrm{P}$ & I & WS/IN \\
\hline $\begin{array}{c}\text { 15. Silver carp } \\
\text { Hypophthalmichth } \\
\text { ys molitrix } \\
\text { (Valenciennes, } \\
\text { 1844) + Bighead } \\
\text { carp } \\
\text { Hypophthalmichth } \\
\text { ys nobilis } \\
\text { (Richardson, 1845) }\end{array}$ & - & + & + & I / ZPD & I & MWS/MN \\
\hline $\begin{array}{l}\text { 16. Sichel Pelecus } \\
\text { cultratus } \\
\text { (Linnaeus, 1758) }\end{array}$ & + & - & - & $\mathrm{N} / \mathrm{Z}$ & I & WS/IN \\
\hline $\begin{array}{l}\text { 17. European } \\
\text { bitterling Rhodeus } \\
\text { amarus (Bloch, } \\
1782 \text { ) }\end{array}$ & + & - & + & $\mathrm{N} / \mathrm{E}$ & NI & MWS/IN \\
\hline $\begin{array}{c}\text { 18. Gudgeon } \\
\text { Gobio gobio } \\
\text { (Linnaeus, 1758) }\end{array}$ & + & - & - & N/B & NI & NWS/IN \\
\hline $\begin{array}{c}\text { 19. Barbel Barbus } \\
\text { barbus (Linnaeus, } \\
\text { 1758) }\end{array}$ & + & - & - & $\mathrm{N} / \mathrm{E}$ & RBU & NWS/S \\
\hline $\begin{array}{l}\text { 20. Common carp } \\
\text { Cyprinus carpio } \\
\text { Linnaeus, } 1758 \\
\end{array}$ & + & + & + & N/B & VI & WS/IN \\
\hline $\begin{array}{l}\text { 21. Crucian carp } \\
\text { Carassius } \\
\text { carassius } \\
\text { (Linnaeus, } 1758 \text { ) }\end{array}$ & + & + & + & $\mathrm{N} / \mathrm{E}$ & RBU & MWS/S \\
\hline $\begin{array}{l}\text { 22. Prussian carp } \\
\text { Carassius gibelio } \\
\text { (Bloch, 1782) }\end{array}$ & - & + & + & $\mathrm{IN} / \mathrm{E}$ & I & $\mathrm{WS} / \mathrm{N}$ \\
\hline $\begin{array}{l}\text { 23. Tench Tinca } \\
\text { tinca (Linnaeus, } \\
\text { 1758) }\end{array}$ & + & + & + & N/B & I & NWS/IN \\
\hline
\end{tabular}


Continuation of Table 2

\begin{tabular}{|c|c|c|c|c|c|c|}
\hline 1 & 2 & 3 & 4 & 5 & 6 & 7 \\
\hline \multicolumn{7}{|c|}{ Cobitidae } \\
\hline $\begin{array}{l}\text { 24. Spined loach } \\
\text { Cobitis taenia } \\
\text { Linnaeus, } 1758\end{array}$ & + & + & + & N/B & NI & WS/IN \\
\hline $\begin{array}{l}\text { 25. Mud loach } \\
\text { Misgurnus fossilis } \\
\text { (Linnaeus, 1758) }\end{array}$ & + & - & - & N/B & I & NWS/S \\
\hline \multicolumn{7}{|c|}{ Siluridae } \\
\hline $\begin{array}{c}\text { 26. Wels catfish } \\
\text { Silurus glanis } \\
\text { Linnaeus, } 1758 \\
\end{array}$ & + & - & + & $\mathrm{N} / \mathrm{P}$ & I & NWS/IN \\
\hline \multicolumn{7}{|c|}{ Esocidae } \\
\hline $\begin{array}{l}\text { 27. Northern pike } \\
\text { Esox lucius } \\
\text { Linnaeus, } 1758\end{array}$ & + & + & + & $\mathrm{N} / \mathrm{P}$ & I & $\mathrm{WS} / \mathrm{MN}$ \\
\hline \multicolumn{7}{|c|}{ Lotidae } \\
\hline $\begin{array}{l}\text { 28. Burbot Lota } \\
\text { lota (Linnaeus, } \\
1758 \text { ) } \\
\end{array}$ & + & - & - & $\mathrm{N} / \mathrm{P}$ & $\mathrm{RBU}$ & NWS/IN \\
\hline \multicolumn{7}{|c|}{ Gasterosteidae } \\
\hline $\begin{array}{l}\text { 29. Southern } \\
\text { ninespine } \\
\text { stickleback } \\
\text { Pungitius } \\
\text { platygaster } \\
\text { (Kessler, 1859) }\end{array}$ & + & + & - & $\mathrm{N} / \mathrm{E}$ & $\mathrm{NI}$ & WS/IN \\
\hline \multicolumn{7}{|c|}{ Percidae } \\
\hline $\begin{array}{c}\text { 30. Ruffe } \\
\text { Gymnocephalus } \\
\text { cernua (Linnaeus, } \\
1758)\end{array}$ & + & - & - & N/B & LI & WS/IN \\
\hline $\begin{array}{c}\text { 31. Donets ruffe } \\
\text { Gymnocephalus } \\
\text { acerina (Gmelin, } \\
1789)\end{array}$ & + & - & - & $\mathrm{N} / \mathrm{P}$ & $\mathrm{RBU}$ & NWS/S \\
\hline $\begin{array}{l}\text { 32. European perch } \\
\text { Perca fluviatilis } \\
\text { Linnaeus, } 1758\end{array}$ & + & + & + & $\mathrm{N} / \mathrm{P}$ & I & WS/IN \\
\hline $\begin{array}{c}\text { 33. Pike-perch } \\
\text { Sander lucioperca } \\
\text { (Linnaeus, 1758) }\end{array}$ & + & - & - & $\mathrm{N} / \mathrm{P}$ & VI & NWS/IN \\
\hline
\end{tabular}


End of table 2

\begin{tabular}{|c|c|c|c|c|c|c|}
\hline 1 & 2 & 3 & 4 & 5 & 6 & 7 \\
\hline \multicolumn{7}{|c|}{ Percidae } \\
\hline $\begin{array}{c}\text { 30. Ruffe } \\
\text { Gymnocephalus } \\
\text { cernua (Linnaeus, } \\
1758 \text { ) }\end{array}$ & + & - & - & N/B & LI & WS/IN \\
\hline $\begin{array}{c}\text { 31. Donets ruffe } \\
\text { Gymnocephalus } \\
\text { acerina (Gmelin, } \\
1789)\end{array}$ & + & - & - & $\mathrm{N} / \mathrm{P}$ & RBU & NWS/S \\
\hline $\begin{array}{l}\text { 32. European perch } \\
\text { Perca fluviatilis } \\
\text { Linnaeus, } 1758\end{array}$ & + & + & + & $\mathrm{N} / \mathrm{P}$ & I & WS/IN \\
\hline $\begin{array}{c}\text { 33. Pike-perch } \\
\text { Sander lucioperca } \\
\text { (Linnaeus, 1758) }\end{array}$ & + & - & - & $\mathrm{N} / \mathrm{P}$ & VI & NWS/IN \\
\hline \multicolumn{7}{|c|}{ Gobiidae } \\
\hline $\begin{array}{l}\text { 34. Monkey goby } \\
\text { Neogobius } \\
\text { fluviatilis (Pallas, } \\
\text { 1814) }\end{array}$ & + & - & - & N/B & NI & WS/MN \\
\hline $\begin{array}{l}\text { 35. Tubenose goby } \\
\text { Proterorhinus } \\
\text { marmoratus } \\
\text { (Pallas, 1814) }\end{array}$ & + & - & - & N/B & NI & WS/MN \\
\hline Total & 33 & 11 & 13 & & & \\
\hline
\end{tabular}

Note: I. Origin, nutrition: $N$-native (original) species; $I$ - introduced species (does not reproduce independently, the number is maintained by stocking); IA - introduced species that have passed the stage of acclimatization, reproduces independently; $S A-$ self-invasive species that have passed the stage of acclimatization. Nutrition: $P h$ - phytophagan; $P h P D$ - phytoplankton and detritus feeder; $Z P$ - zooplankton feeder; $Z P D$ - zooplankton and detritus feeder; $Z$-zoophage; $E$ - euriphage; $B$ - bentophage; $P$ - a predator.

II. Resource value: VI-valuable industrial species; I-industrial species;

LI-low-value industrial species; NI-non-industrial species; PI-potentially industrial species, RBU - listed in the Red Book of Ukraine.

III. Distribution, number: WS - widespread species; MWS - moderately widespread species; NWS - not widespread species; $N$-numerous species; $M N$ - moderately numerous species; IN - insignificantly numerous species; $S$-single species.

The trophic structure of the industrial ichthyocenosis consists of groups of euryphages, benthophages, planktophages, and predatory fish. Among the industrial ichthyofauna, euryphages numerically dominate, reaching $69.15 \%$ and bentophages, reaching $26.63 \%$ of the population. The smallest groups are represented by planktophages $(0.26 \%)$, which is naturally caused by the 
absence of stocking with silver carp. The predator group is equal to $3.66 \%$ and is represented by catfish, pike and perch.

Thus, beginning from the moment of regulation of the Samotkan River (1960-1963) the following changes have occurred in the ichthyocenosis of the Pershotravensk reservoir and adjacent water areas. The species composition has decreased from 33 species to 14 species due to the disappearance of representatives of the rheophilic group of fish (dace, chub, nase, riffle minnow, gudgeon, barbel, white-eye bream, blue bream, Donets ruffe, burbot, sabrefish, asp, and monkey goby). Valuable species of the resource group, such as zander, are not registered. The ichthyofauna lacks ide and loach, which are rare in the region, as well as such typical species of the estuarine areas of the steppe zone as silver bream, tube goby, and ruff. Replenishment of the species composition occurred at the expense of Prussian carp and herbivorous fish carp (hybrid forms of silver carp and bighead carp). In general, most biotopes are occupied by rudd, bitterling, belica, perch, which are massively found in the littoral (up to 352.0 ind. $/ 100 \mathrm{~m}^{2}$ ).

Among the studied species, the Crucian carp has the status of a protected species and is listed in the Red Book of Ukraine.

The relative difficulty of the survival process of the aboriginal ichthyocenosis of the Pershotravenske reservoir is evidenced by the following. All the studied coastal waters (upper reaches, middle part, area near a dam), are dominated by the first generations of rudd, belica, bitterling and Prussian carp.

At the same time, it is worth noting that the studied reservoir plays a significant role in the restoration of two functionally important rare aboriginal species in the region - tench and Crucian carp, the density of which indicates relatively favourable conditions for the process of their replenishment. In some biotopes, the number of tench fingerlings reaches 115.18 ind. $/ 100 \mathrm{~m}^{2}$, that of Crucian carp fingerlings reaches 160.3 ind. $/ 100 \mathrm{~m}^{2}$.

That aside, despite the relative intensity of the recovery process, which is typical for most small reservoirs in the region, the Pershotravenske Reservoir is of great significance for the process of replenishing the ichthyofauna of open watercourses of the steppe zone of Ukraine. The water area of the reservoir has initial characteristics (the presence of various types of biotopes, including the flood plain type in upper reaches) for a balanced existence of ichthyofauna.

Structural organization of aquatic bioresource species. Structural and functional indicators of the ichthyofauna of the Pershotravenske Reservoir have been determined based on the results of control catches. Catches were carried out in 2019 based on Permit No. 000025/2019 dated October 02, 2019. A set of fish stakes with a bar of $30-100 \mathrm{~mm}$ (in October), as well as minnow seine (in August-September; $a=8-10 \mathrm{~mm}$ ), was used for control 
catches. Data on the population structure of the main commercial fish and their parameters are provided in Tables 3-4.

The main species of aquatic bioresources currently living in the Pershotravensk Reservoir belonging to the nonmigratory fauna include Prussian carp, perch, rudd, Crucian carp, pike, tench, roach, and bream. The introduced species include carp and a hybrid of the silver carp.

Prussian carp. The species is one of the dominant species among native ichthyofauna in the industrial group. It effectively develops the entire water area and all types of biotopes, such as deep areas of the pelagic zone, upper reaches, coastal areas, and the area near the dam. The species origins from the initial population that lived in the reservoir before the beginning of its fishery operation. It was formed as a result of stocking in the 60s and 90s of the twentieth century, which was carried out partly purposefully, and partly chaotically, mainly by the pond (stunted) form of Prussian carp. As a result, the pond Prussian carp massively occupied small reservoirs and their coasts. This stunted form of pond Prussian carp with a body size of a brood fish of up to $10 \mathrm{~cm}$ is characterized as eurybiontic in most parameters. Slowgrowing brood fish spawn almost throughout the summer on any substrate. This creates a competitive burden on the feed base, especially in the coastal areas. This form is very difficult to extract industrially, including reclamation fishing. Its presence in water bodies is the first sign of destabilization of ichthyofauna homeostasis. In this aspect, the Pershotravenske Reservoir differs from most small reservoirs in the region. A full-fledged population of Prussian carp inhabits its water area. The age structure of the Prussian carp population consisted of 7 classes in females (from 3 to 9 years), and 8 classes in males (from 2 to 9 years). The basis of the catch consisted of 4 years old individuals.

Indicators of linear growth of Prussian carp ranged from 15 to $28.5 \mathrm{~cm}$. The mass indicators of Prussian carp ranged from $70 \mathrm{~g}$ to $560 \mathrm{~g}$; the average mass of individuals is $511.5-15.5 \mathrm{~g}$. The rate of size and weight growth by age classes is gradual and stable; in older individuals (6+), the growth rate has not slowed down, representatives of this group reach a size of $25.0 \mathrm{~cm}$ with a mass of $0.3-0.5 \mathrm{~kg}$. The average values of the condition factor of Prussian carp were 3.1-0.24 units. The conditions of reproduction of Prussian carp in the reservoir indicate a trend to develop the population size; in the littoral of the reservoir, the number of fingerlings averages to 286.25 ind./100 $\mathrm{m}^{2}$, which is $23.85 \%$ of the total population of the species (table 3 ). This is evidence of favourable conditions for spawning and further feeding of the species youth in the middle part of the reservoir.

Thus, further stocking of the reservoir with any form of Prussian carp is inexpedient. On the other hand, this species does not need any additional 
land reclamation measures to be carried out. Annual extraction (industrial and amateur) of this species is a sufficient measure to regulate its number.

Table 3

Species composition, age and numerical parameters of fish groups of the Pershotravenske Reservoir (per $100 \mathrm{~m}^{2}$ )

\begin{tabular}{|c|c|c|c|c|}
\hline \multirow{2}{*}{ Species of fish } & \multirow{2}{*}{ Age } & \multicolumn{3}{|c|}{ Averaged over the entire reservoir } \\
\cline { 2 - 5 } & & $\mathbf{x}$ & $\mathbf{\%}$ & $\mathbf{y}$ \\
\hline \multirow{3}{*}{ 1. Rudd } & $0+$ & 45.92 & 5.40 & 17.97 \\
\cline { 2 - 5 } & $1+$ & 14.38 & 1.27 & 23.37 \\
\cline { 2 - 5 } & $2+$ & 0.99 & 0.17 & 6.24 \\
\cline { 2 - 5 } & $3+$ & 1.15 & 0.08 & 54.63 \\
\hline \multirow{2}{*}{ 2. Roach } & $0+$ & 2.92 & 0.47 & 2.12 \\
\hline & $1+$ & 1.37 & 0.20 & 3.42 \\
\hline 3. Belica & - & 374.50 & 40.63 & 246.35 \\
\hline \multirow{2}{*}{ 4. Crucian carp } & $0+$ & 53.45 & 3.59 & 50.07 \\
\cline { 2 - 5 } & $1+$ & 4.37 & 0.29 & 13.29 \\
\hline \multirow{2}{*}{ 5. Prussian carp } & $0+$ & 286.25 & 23.85 & 149.72 \\
\cline { 2 - 5 } & $1+$ & 89.26 & 7.74 & 277.20 \\
\hline \multirow{3}{*}{ 6. Tench } & $0+$ & 58.00 & 5.01 & 36.27 \\
\cline { 2 - 5 } & $1+$ & 6.68 & 0.72 & 9.11 \\
\cline { 2 - 5 } & $2+$ & 1.07 & 0.10 & 5.24 \\
\hline 7. Spined loach & - & 1.26 & 0.12 & 2.26 \\
\hline 8. Northern pike & $0+$ & 1.25 & 0.09 & 8.99 \\
\hline 9. European perch & $1+$ & 9.94 & 0.92 & 5.37 \\
\hline \multirow{2}{*}{ 10. European bitterling } & $0+$ & 74.07 & 6.99 & 29.15 \\
\hline Total & $1+$ & 26.65 & 2.34 & 30.21 \\
\hline Valuable industrial & & 1053.49 & 100.0 & 970.98 \\
\hline species & & & & \\
\hline Industrial species & & 519.23 & 46.04 & 599.73 \\
\hline Non-industrial species & & 534.26 & 53.96 & 371.26 \\
\hline
\end{tabular}

Note: $X$-number, ind. $/ 100 m^{2} ; y$ - biomass, $g / 100 m^{2}$;

$\%$ - the share of the total population

Crucian carp. It belongs to the fish listed in the Red Book of Ukraine. It is sometimes found in the catches of anglers. The average linear weight indicators were: length $-20.3 \pm 1.15 \mathrm{~cm}$, weight $-210.0 \pm 25.3 \mathrm{~g}$. The ratio of males to females in the herd is $1: 1$.

Pershotravenske Reservoir has the largest number of this species among the studied small reservoirs of the region. Within the steppe zone of Ukraine, the Crucian carp was replaced everywhere by the Prussian carp during the $60-90$ s of the last century. It is recorded as single individuals in local water 
areas separated from the main watercourses (small rivers of the II, III order, ponds, etc.). In the Pershotravensk reservoir (in the area near a dam), the number of fingerlings of the species is 160.34 ind./100 m², which is $10.77 \%$ of the numerical indicators of coastal groupings (table 3). All individuals of the Crucian carp were analyzed without removal from their habitat and released alive and unharmed. The living conditions of the species in the reservoir meet all the functional (spawning, trophic, wintering) needs of the species. To preserve the population, several measures should be implemented, the list of which is presented in our work.

Rudd. As part of the aboriginal ichthyocomplex, it was the dominant species, however now it has become a secondary species, whose catches in control fishing gear reach $0.05 \%$. In experimental areas, rudd is a common species, which is caught by anglers. The average linear weight indicators are the following: length $-21.5 \pm 2.65 \mathrm{~cm}$, weight $-210.0 \pm 25.2 \mathrm{~g}$. The average age of individuals is 5 years. The ratio of males to females in the herd is 1:1. With the total number of small ordinary fish species ranging from 0.5 to 2.0 ind./ 1 industrial effort, the number of rudd on average in the reservoir reaches 0.13 ind./ 1 industrial effort, from the total indicators. This is explained both by a wide range of adaptive reactions of the species (euryphagous fish) and by the presence of conditions for effective spawning, feeding of juveniles and the further existence of older age groups. Thus, in particular, in the coastal zone, the full age range of the first generations of the species is formed, from fingerlings to 3-year-old individuals (Table 3). The number of fingerlings in the upper reaches is 68.76 ind. $/ 100 \mathrm{~m}^{2}$, representing $11.57 \%$ of the total fish number of the upper littoral. The number of the species is stable and can be used for a fishery, both for industrial and reclamation catches, and for the amateur fishing.

Roach. The average length of roach individuals was $22.25 \pm 0.21 \mathrm{~cm}$ in females and $20.29 \pm 0.28 \mathrm{~cm}$ in males. The mass of fish ranged from $75 \mathrm{~g}$ to $290 \mathrm{~g}$, the average weight was $196.0 \pm 13.5 \mathrm{~g}$. The age of roach individuals ranged from 2 to 8 years, with an average of 4-6 years. The Fulton's condition factor was $1.6 \pm 0.1$ units and fat content was 3-4 points.

Perch. The reservoir is dominated by a slow-growing form of this species. The catches were dominated by individuals aged 3-8 years. The average length of perch was $20.88 \pm 1.44 \mathrm{~cm}$, the average weight reached $143.1 \pm 23.22 \mathrm{~g}$ and the average age were 5 years. The ratio of males and females in the herd was 1:1. The number of individuals with a body size of more than $15.0 \mathrm{~cm}$ (older than 4 years) is insignificant and reaches 0.1 ind./ 1 industrial effort, while the number of small individuals reaches 5.0 ind./ 1 industrial effort. The number of first generations of the species in fry control catches averages at 9.94 ind./100 $\mathrm{m}^{2}$. Thus, there are good reasons to carry out regulated extraction in the process of industrial and amateur fishing. 
Pike. This species is a valuable predator for the biological melioration. It prefers slow-flowing watercourses. It grows quite quickly, especially in the first years of life before sex maturity. In the studied reservoir, fingerlings reach a mass of $100 \mathrm{~g}$, two-year-olds reach up to $980 \mathrm{~g}$, and three-year-olds reach up to $1400-1900 \mathrm{~g}$. The average weight of individuals is $2500 \pm 350.4 \mathrm{~g}$. The general age series of the pike population in the reservoir is reduced and consists of 4 age classes, the reproductive part of the population are represented by 3 - and 4-year-old individuals. The population is sparse, although the breeding conditions are quite optimal, thus, the number of fingerlings of the species in the coastal areas is 1.25 ind./100 $\mathrm{m}^{2}$ (table 3). The number of this species in the pelagic part (0.2 ind./1 industrial effort) is sufficient to perform the reclamation function of this species as a predator. However, since the pike also actively consumes young species introduced by fisheries, additional stocking is not advisable. Intensive commercial extraction of the species should also be limited; however, the pike is a promising object of amateur fishing.

Tench. A commercial species that is often found in the catches of anglers (individuals caught by anglers were analyzed) near thickets of reeds and pondweed. The average length of tench was $22.19 \pm 1.25 \mathrm{~cm}$, the average weight reached $290.0 \pm 25.31$. The age structure of the population was not determined. It was found that the tench reaches sexual maturity at linear and weight parameters of $16-18 \mathrm{~cm}$ and $0.08-0.1 \mathrm{~kg}$, which are reached probably at the age of 4 years. Individuals of $12-14 \mathrm{~cm}$ length and weighing $0.05-0.08 \mathrm{~kg}$ had Stage III of the sexual products development. The reservoir is inhabited by a stable tench population; the number of fingerlings in the coastal area reaches 115.18 ind./100 $\mathrm{m}^{2}$, which is $7.73 \%$ of the number of coastal fish groups. On average, the number of this species in the reservoir is 58.88 ind. $/ 100 \mathrm{~m}^{2}$, which is $5.01 \%$. Unlike other small reservoirs in the region, this reservoir contains has a significant commercial stock of this species, which is a valuable object of industrial and amateur fishing.

Catfish. Catfish is poorly subjected to the main cropping due to the low efficiency of fishing gear. Today, catfish is largely caught by anglers (mainly in spearfishing), who capture fish of extreme age groups. The average weighted mass of catfish individuals reached $1890 \pm 320.4 \mathrm{~g}$. The commercial length of individuals ranged from 52.0 to $77.0 \mathrm{~cm}$ and averaged at $65.21 \pm 5.45 \mathrm{~cm}$. The number of this species in the pelagic part of the reservoir is 0.23 ind./ 1 industrial force.

Bream. The maximum age in catches reached 6 years for both females and males. The number of age classes was at the level of 5. The core of the bream population was 3 to 5 years old individuals. The length of bream according to control catches ranged from 25.4 to $30.5 \mathrm{~cm}$; mass indicators ranged from 280 to $900 \mathrm{~g}$, the average weight was $486.8 \pm 25.7 \mathrm{~g}$. Middle-aged values of Fulton’s 
condition factor were kept at the level of 2.5-3.0 units. The number of this species in the pelagic part of the reservoir is 3.3 ind./ 1 industrial effort).

\section{Introduced species.}

Silver carp (hybrid form). Since this species does not reproduce naturally in the reservoirs of the region, structural indicators of the population were not determined. Currently, a group of silver carp aged 1516 years inhabits the Pershotravensk reservoir. This is the result of stocking in 2006 with yearlings and two-year-olds weighing 15-20 g and 300-330 g, respectively. Given the state of the food supply (phyto-, zooplankton) and the rate of linear and weight growth, this hybrid form consumes phyto- and zooplankton, as well as detritus, but feeds more intensively on zooplankton. Linear and weight growth of this fish has the maximum parameters among water bodies in the region. Thus, according to preliminary data of 2008, four-year-olds (3+) (stocking with yearlings in 2006) had a size of 55.0-65.0 $\mathrm{cm}$ with a mass of $3.75-4.5 \mathrm{~kg}$, respectively. The linear and weight parameters of five-year-olds (4+) are also increased and amount to 70.0-75.0 $\mathrm{cm}$ with a weight of $6.0-7.0 \mathrm{~kg}$. During the control catch, an individual weighing $21.45 \mathrm{~kg}$ was caught, which is the remainder of the 2006 stocking, since the age of the individual was 16 years. The accumulation of individuals of older age groups permits reclamation catches of large individuals, since the silver carp does not reproduce naturally under the conditions of the reservoir, and older individuals will simply die over time.

The rate of weight growth outpaces the average indicators in small reservoirs with pasture fish farming, at least 1.5 times. Thus, the Pershotravenske reservoir has a sufficient potential resource for the intensification of the fisheries process, but under observance of optimal volumes of herbivorous fish stocking.

Carp. The origin of the species is the result of stocking the reservoir with 2-years-old pond carp in 2006. The native, original form of carp has not been registered in the reservoir. The carp reserve was formed by stocking in 2006, which individuals created a self-sustaining population.

The age series of carp is represented by 9 classes (3-12-years-olds). The core of the carp population consisted of 4-6-years-olds. The length of individuals ranged from 28.0 (in 3-year-olds) to $54.2 \mathrm{~cm}$ (in 9-year-olds). The mass of carp ranged from $1280 \mathrm{~g}$ to $6500 \mathrm{~g}$, an average was $3850.0 \pm 55.2 \mathrm{~g}$. In certain cases, there were individuals aged 9 years and weighing up to $6 \mathrm{~kg}$. Fulton's condition factor is $2.3 \pm 0.3$ units. The ratio of males to females was $55 \%$ and $45 \%$, respectively.

The rate of linear and weight growth corresponds to the standard rate for reservoirs of this class. At the age of three, individuals have linear and weight parameters of $28.0-28.2 \mathrm{~cm}$ with a weight of 1.1-1.4 kg. Four-year-old individuals reach a size of $40.0-42.0 \mathrm{~cm}$, and a weight of $2.2-2.6 \mathrm{~kg}$. Currently, the number of carp is up to 0.6 ind./1 industrial force (table 4). Following the 
linear and weight indicators of carp and the growth rate and feed base, the conditions in the reservoir are suitable for the use of carp in multi-culture. At the same time, the lack of significant development of forage base (benthos), due to their intensive consumption (including by other fish species, especially Prussian carp), indicates the need for strict compliance with the calculated volumes of stocking and catch (provided below).

The population structure of non-commercial species of native ichthyofauna, mainly of the short-cycle group (belica, spined loach, bitterling) has not been studied.

\section{Fisheries characteristics}

As already stated, the Pershotravenske Reservoir was created for flood regulation, prevention of flooding of adjacent territories and transit of industrial water from the system of storage reservoirs of the Vilnohirsk Mining and Metallurgical Complex in the Dnipro River (Kamyanske reservoir).

The primary user is the Kamyansk Regional Department of Water Resources. Therefore, the fishing operation of the reservoir until 2006 was occasional, stocking did not occur annually, it was performed in arbitrary volumes, the operation was carried out without taking into account the volume of stocking and catch, withdrawal was carried out by collective farms, residents, by illegal fishing.

These conditions led to the absence of fish species (carp, silver carp) in the reservoir at the time of previous studies (2007-2008). Since 2006, the fisheries operation of the Pershotravenske Reservoir has been carried out by TOV Alpha-teks Company, which carried out stocking in 2006 in the amount of 19.5 thous. ind. To date, there is no organized fisheries use of the reservoir.

Fish productivity of the reservoir. Initial indicators of the state of the feed base and ichthyofauna show that currently, the reservoir has a sufficient supply of fish resources to start commercial extraction, both for the group of introduced species and for native fauna, with prospects for intensifying the process of fisheries activities in a complex use mode.

Prussian carp. The Industrial return rate from fingerlings is $20 \%$. The annual average number of two-year-olds of Prussian carp in the coastal areas of the reservoir is 89.26 ind./100 $\mathrm{m}^{2}$ (8926.0 ind./ha), the area of biotopes where young Prussian carps are concentrated (depths up to $1.5 \mathrm{M}$ ) is $30 \%$ of the total, which is $50 \mathrm{ha}$, the average weight of mature individuals is $0.13 \mathrm{~kg}$. The expected commercial stock of Prussian carp in the reservoir (E) is:

$$
E=\frac{8926.0 \cdot 20 \cdot 50}{100} \cdot 0.13=11604 \mathrm{~kg} \text {. }
$$




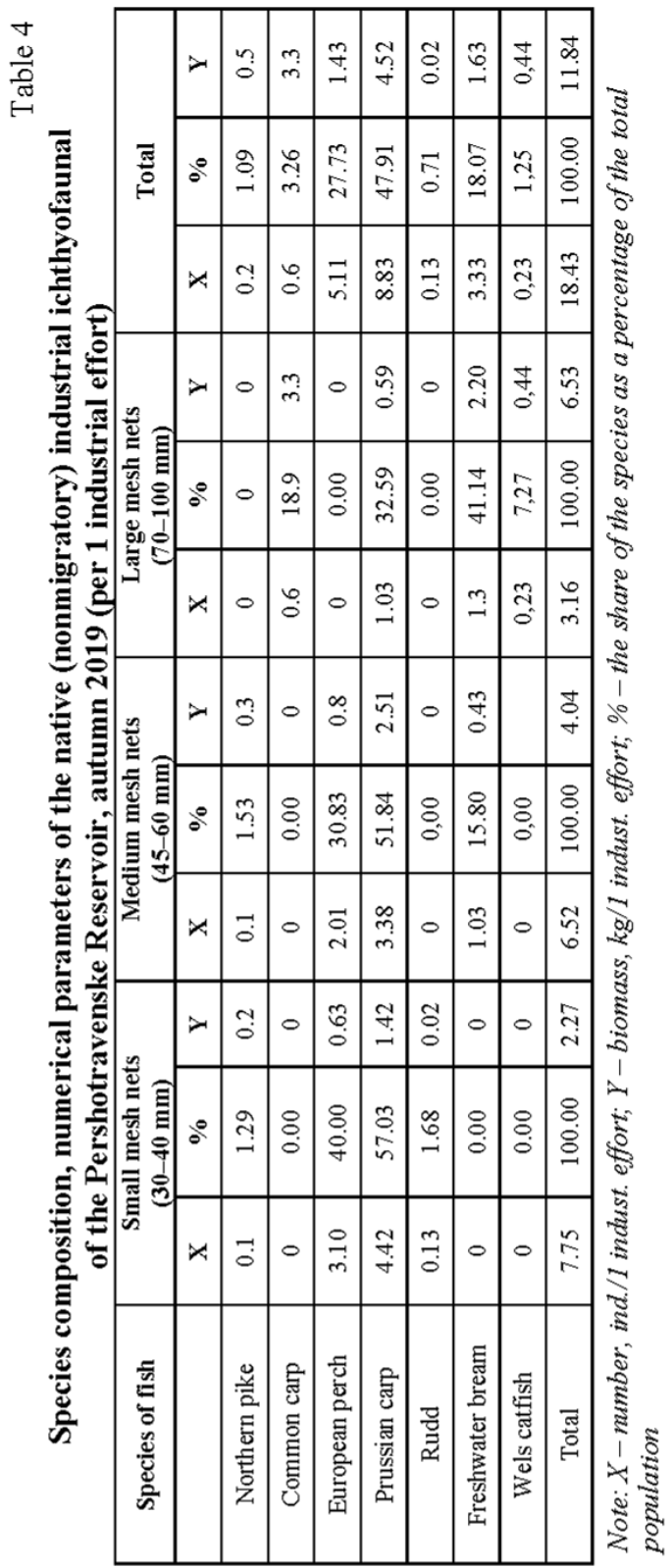


Thus, the expected commercial stock of Prussian carp is $11,604 \mathrm{~kg}$; fish productivity is $77.15 \mathrm{~kg} / \mathrm{ha}$. The expected catch of Prussian carp is $2320 \mathrm{~kg}$.

Rudd. The commercial return rate of carp species from fingerlings is $20 \%$. The annual average density of two-year-old rudd in the coastal areas of the reservoir is 14.38 ind./100 $\mathrm{m}^{2}$ (1438.0 ind./ ha), the area of biotopes where rudd juveniles are concentrated (depths up to $1.5 \mathrm{M}$ ) is $30 \%$ of the total, which is $50 \mathrm{ha}$, the average weight mature of individuals is $0.07 \mathrm{~kg}$. The expected commercial stock of rudd in the reservoir $(\mathrm{E})$ is:

$$
E=\frac{1438.0 \cdot 50.0 \cdot 20}{100} \cdot 0.07=1007 \mathrm{~kg} .
$$

Thus, the expected commercial stock of rudd is $1007 \mathrm{~kg}$, fish productivity is $6.70 \mathrm{~kg} / \mathrm{ha}$.

The extraction of rudd (as a native species) should be systematic, permanent (during industrial, amateur and reclamation catches). Taking into account the absence of nets with a mesh size less than $42 \mathrm{~mm}$, the estimated volume of withdrawal will be $10 \%$ of the total stock, that is, $100 \mathrm{~kg} / \mathrm{year}$.

Roach. The commercial return rate of carp species from fingerlings is $20 \%$. The annual average density of two-year-old roach in the coastal areas of the reservoir is 1.37 ind./100 $\mathrm{m}^{2}$ (137.0 ind./ha), the area of biotopes where roach juveniles are concentrated (depths up to $1.5 \mathrm{~m}$ ) is $30 \%$ of the total, which is $50 \mathrm{ha}$, the average weight mature of individuals is $0.2 \mathrm{~kg}$. The expected commercial stock of roach in the reservoir (E) is:

$$
E=\frac{137.0 \cdot 50.0 \cdot 20}{100} \cdot 0.2=274 \mathrm{~kg} \text {. }
$$

Thus, the expected commercial stock of roach is $274 \mathrm{~kg}$; fish productivity is $1.82 \mathrm{~kg} / \mathrm{ha}$.

The extraction of roach (as a native species) should be systematic, permanent (during industrial, amateur and reclamation catches). However, it is worth to limit the volume of withdrawal to $25 \%$ of the total stock, that is, $70 \mathrm{~kg} /$ year.

Perch. The density of two-year-old perch in the reservoir is 9.94 ind.$/ 100 \mathrm{~m}^{2}$, the average weight of sexually mature individuals is $0.13 \mathrm{~kg}$, the commercial return rate from annuals is $20 \%$. The water area of youth concentration (depths up to $1.5 \mathrm{~m}$ ) is 50 ha $(30 \%$ of the total). The commercial stock of perch in the Pershotravenske Reservoir is:

$$
E=\frac{994.0 \cdot 50.0 \cdot 20}{100} \cdot 0.13=1292 \mathrm{~kg} .
$$

Thus, the expected commercial stock of perch is $1292 \mathrm{~kg}$, fish productivity is $8.59 \mathrm{~kg} / \mathrm{ha}$. 
The extraction of perch (as a native species) should be systematic, permanent (during industrial, amateur and reclamation catches). However, it is worth to limit the volume of withdrawal to $25 \%$ of the total stock, that is, $323 \mathrm{~kg} /$ year.

Tench. The commercial return rate (before reaching maturity) from oneyear-olds is $20 \%$. The annual average density of two-year-old tench in the coastal areas of the reservoir is 6.68 ind./100 $\mathrm{m}^{2}$ (668.0 ind./ ha), the area of biotopes where one-year-old tench are concentrated (depths up to $1.5 \mathrm{~m}$ ) is $30 \%$ of the total, which is 50 ha, the average weight of mature individuals is $0.2 \mathrm{~kg}$. The expected commercial stock of tench in the reservoir $(\mathrm{E})$ is:

$$
E=\frac{668.0 \cdot 50.0 \cdot 20}{100} \cdot 0.2=1336 \mathrm{~kg} \text {. }
$$

The share of industrial tench contingents in catches of 2019 was 20\%, that is, the expected commercial stock of tench is $267 \mathrm{~kg}$, fish productivity is $1.78 \mathrm{~kg} / \mathrm{ha}$.

Since this species is poorly widespread in the region, it is necessary to limit the amount of its withdrawal to preserve the original population of the species. The volume of withdrawal is $20 \%$ in the first year of operation, i.e. $53.44 \mathrm{~kg}$. Further withdrawal should be carried out mainly in the incidental catch mode when fishing for Prussian carp and during amateur fishing.

Pike. The commercial return rate (before reaching maturity) from fingerlings is $10 \%$. The average annual density of pike fingerlings in the littoral of the reservoir is 1.25 ind./100m ${ }^{2}$ (125.0 ind./ ha), the area of biotopes where pike juveniles are concentrated (depths up to $1.5 \mathrm{~m}$ ) is $30 \%$ of the total, which is 50 ha, the average weight of mature individuals of industrial measure (more than $35 \mathrm{~cm}$ ) is $0.44 \mathrm{~kg}$. The expected commercial stock of pike in the reservoir $(\mathrm{E})$ is:

$$
E=\frac{125.0 \cdot 50.0 \cdot 10}{100} \cdot 0.44=275 \mathrm{~kg} .
$$

Thus, the expected commercial stock of pike in the reservoir is $275 \mathrm{~kg}$, fish productivity is $1.83 \mathrm{~kg} / \mathrm{ha}$.

Since pike is a functionally valuable species (reclamation function), the withdrawal (both industrial and amateur) of this species should be limited to about $20 \%$ of the initial stock, that is, an average of $55 \mathrm{~kg}$ annually.

Bream. Taking into account the natural mortality rate $(0.20)$, the catch rate (0.26), the presence of individuals of older age groups (the catch per 100 net days of large-mesh nets in 2019 was 130 ind. (120 kg)), the fish productivity of bream can be estimated as $25.72 \mathrm{~kg} / \mathrm{ha}$, which corresponds to a stock of $3868 \mathrm{~kg}$. Given the low rates of replenishment by young fish, it is advisable to set the limit of bream catch in 2020 to no higher than $25 \%$ of the total stock, which is $967 \mathrm{~kg}$. 
Catfish. Analysis of control fishing gear showed that in 2019, there were 23.2 ind. per 100 net days. $(44.3 \mathrm{~kg})$. The indicator of fish productivity is about $1.737 \mathrm{~kg} / \mathrm{ha}$, respectively, the catfish stock can be estimated at $260 \mathrm{~kg}$. The expected permissible catch of catfish in 2020 can be estimated at $65 \mathrm{~kg}$.

Silver carp. Analysis of control fishing gear showed that in 2019, there were 3.3 ind. per 100 net days. ( $71.5 \mathrm{~kg}$ ). The stock is formed by the remains from stocking in 2006. The stock of silver carp is represented by old-aged individuals and reaches $521 \mathrm{~kg}$. Given the biology of reproduction of silver carp, its catch can be taken as $30 \%$ of the stock.

Given the presence of old-age individuals of silver carp, the reproduction of which is carried out artificially, it is worth to use large mesh nets with a bar of $\mathrm{a}=100-180 \mathrm{~mm}$ for specialized fishing of herbivorous fish and older age groups of other fish species to regulate the load on the formed stock and harvesting of breeders.

Carp. Individuals that were stocked in 2006 formed the modern population. Although the population is self-reproducing, as evidenced by the presence of individuals of different ages, natural reproduction is at a rather low level, which is confirmed by the absence of carp juveniles in the catches of minnow seine. The excessive number of Prussian carp may be one of the reasons. Analysis of control fishing gear showed that in 2019, there were 6.6 ind. per 100 net days $(33.4 \mathrm{~kg})$. The stock of carp is about $250 \mathrm{~kg}$. The total stock of fish species is shown in table 5 .

Table 5

The total commercial stock of ichthyofauna and fish productivity indicators of the Pershotravenske Reservoir

\begin{tabular}{|c|c|c|}
\hline Fish species & Stock, kg & Fish productivity, kg/ha \\
\hline Prussian carp & 11603 & 77.15 \\
\hline Rudd & 1007 & 6.70 \\
\hline European perch & 1292 & 8.59 \\
\hline Tench & 267 & 1.78 \\
\hline Northern pike & 275 & 1.83 \\
\hline Freshwater bream & 3868 & 25.72 \\
\hline Wels catfish & 260 & 1.73 \\
\hline Silver carp + Bighead carp & 521 & 3.46 \\
\hline Common carp & 250 & 1.66 \\
\hline Roach & 274 & 1.82 \\
\hline Total & 19617 & 131.75 \\
\hline
\end{tabular}

Potential fish productivity due to fish introduction. Since the reservoir has additional potential for intensifying the fisheries process in terms of the residual feed base, it is necessary to calculate additional (potential) fish production due to stocking by herbivorous fish and carp. 
Grass carp. Potential fish production upon indications of aquatic vegetation development is determined by the formula ${ }^{14}$ :

$$
M=\frac{1}{2} \cdot \frac{A}{F c},
$$

where $\mathrm{M}$ is potential fish production, $\mathrm{kg} / \mathrm{ha}$; $\mathrm{A}$ is products of the natural feed base, $\mathrm{kg} / \mathrm{ha} ; 1 / 2$ is the utilization rate of organic matter products $(50 \%) ; \mathrm{Fc}$ is the feed coefficient of natural feed.

The potential fish production (Msp) due to submerged aquatic plants will be equal to, with organic matter production of $13750 \mathrm{~kg} / \mathrm{ha}$, taking into account the area of overgrowth and the feed coefficient of 30 :

$$
M s p=\frac{1}{2} \cdot \frac{13750.0}{30}=229 \mathrm{~kg} / \mathrm{ha} .
$$

To obtain such a large amount of fish products at the expense of the consumer of this type of feed (grass carp), it is necessary to carry out an annual stocking with a planting density $(\mathrm{Pt})$.

$$
P t=\frac{D g c}{I W},
$$

where Dgc is the density of stocking with grass carp; IW is individual weight gain during the season, $\mathrm{kg}$;

$$
P t=\frac{229}{0,5}=458 \text { ind } . / \text { ha. }
$$

Since the area of overgrowth of submerged aquatic plants is 50 hectares, the total maximum number of grass carp $(\mathrm{Ngc})$ that can consume the entire volume of submerged aquatic plants is equal to $\mathrm{Ngc}=458 \mathrm{~kg} / \mathrm{ha} \times 50 \mathrm{ha}=22900$ ind.; $\mathrm{Ngc}$ is the maximum number of grass carp, ind.

Since most species of hydrophytes in our reservoirs make up a small segment in the nutrition of grass carp, to prevent excessive load on hydatophytes, semi-submerged plants were not taken into account in the calculations of the potential feed base.

To obtain a biomeliorative effect and free the reservoir from excess phytomass, it is enough to withdraw $30 \%$ of the phytomass of submerged and air-water plants annually. Therefore, to obtain additional fish products at the expense of grass carp, it is advisable to carry out primary stocking of the reservoir in the amount of $45 \%$ of the maximum volume, that is, 10,200 fingerlings or 5,100 specimens, two-year-olds (the increased predicted mortality of Fingerlings is due to the high specific number of predators in typical feeding biotopes of this species). The potential fish productivity of the reservoir, with a commercial return rate of $20 \%$ and an average annual growth of grass carp to reach an industrial size $(40 \mathrm{~cm})$ and a

14 Пидгайко М.Л. Потенциальная продукция. Методы определения продукции водных животных. Минск, 1968. 
mass of $1.5 \mathrm{~kg}$, is $3100 \mathrm{~kg}$, i.e. $20.6 \mathrm{~kg} / \mathrm{ha}$ due to the introduction of 1 generation. In prospect, it is required to maintain stocking with grass carp in the amount of 5100 fingerlings or 2600 of two-year-old individuals.

Silver carp. Potential fish production due to phytoplankton is determined similarly, taking into account phytoplankton production of $53100.0 \mathrm{~kg} / \mathrm{ha}$ and a feed coefficient of 50 :

$$
M=\frac{1}{2} \cdot \frac{53100.0}{50}=531 .
$$

The density of additional stocking with silver carp, the main consumer of phytoplankton and the standard mass gain for this type of reservoirs of the region of $2.5 \mathrm{~kg}$ due to the residual mass of phytoplankton (natural food base) is equal to:

$$
P t=\frac{531}{2.5}=212.4 \mathrm{ind} . / \mathrm{ha} .
$$

The area of silver carp feeding biotopes is $75 \%$, that is, 100 hectares. Therefore, the total number of silver carp that can be additionally stocked into the reservoir is equal to:

$$
\mathrm{Ngc}=212.4 \text { ind. } / \text { ha } \mathrm{x} 100 \mathrm{ha}=21240 \text { ind. }
$$

The indicated amount of stocking with silver carp (an average of 21,000 ind. of fingerlings and one-year-olds), will contribute to maintaining a balanced process of utilization of excess of this group of organisms. It is also permissible to carry out a stocking with two-year-olds in the amount of $75 \%$ of the calculated number of one-year-olds, that is, an average of 15,700 ind.

With a commercial return rate of $20 \%$, the volume of additional fish products from one stocked generation will amount to 21,000 ind. $x(20 \%)=$ 4200 ind. weighing at least $2.5 \mathrm{~kg}$, i.e. $10500 \mathrm{~kg}$. Further, it is necessary to maintain stocking at a rate of $50 \%$ of the primary one.

Potential fish production due to zooplankton with a zooplankton production value of $495 \mathrm{~kg} / \mathrm{ha}$ and a feed coefficient of 6 , is determined similarly:

$$
M=\frac{1}{2} \cdot \frac{495}{6}=41.25 \mathrm{~kg} / \mathrm{ha} .
$$

The density of the main consumer of zooplankton, the bighead carp and its hybrid form, taking into account the annual growth of $2.5 \mathrm{~kg}$, is equal to:

$$
P t=\frac{41.25}{2.5}=16.5 \text { ind } . / \mathrm{ha}
$$

The total number of bighead carp that can be additionally introduced into the reservoir is equal to: 


$$
\mathrm{Nbc}=16.5 \times 100=1650.0 \text { ind. }
$$

An additional amount of stocking with bighead carp (an average of 1600 fingerlings or 1200.0 two-year-olds), as in the case of the silver carp, concerns the period of 2020. If the optimal removal of the bighead carp is not more than $80 \%$, it is permissible in the future (starting from 2021) to stock annually at the rate of $80 \%$ of the planned amount, that is, 1200 ind. of fingerlings. With a commercial return rate of $20 \%$, the volume of additional fish products from one stocked generation will amount to 1200 ind. $x(20 \%)=240$ ind. weighing at least $2.5 \mathrm{~kg}$, i.e. $600 \mathrm{~kg}$. It is permissible to carry out a further stocking with two-year-olds, in the amount of $75 \%$ of the number of fingerlings, that is, 900 ind.

Potential additional fish production due to zoobenthos with a residual output of this group of feed objects of $420.0 \mathrm{~kg} / \mathrm{ha}$ and a feed coefficient of 5 is determined similarly:

$$
M=\frac{1}{2} \cdot \frac{420.0}{5}=42 \mathrm{~kg} / \mathrm{ha} .
$$

The density of the main consumer of zoobenthos, carp ( $\mathrm{Nc}$ ), taking into account the annual growth of $0.5 \mathrm{~kg}$, is equal to:

$$
P t=\frac{42,0}{0,5}=84 \text { ind } . / \text { ha. }
$$

The area of carp feeding biotopes is $90 \%$, i.e. 135 hectares. Therefore, the total number of fingerlings and one-year-olds of carp that can be additionally stocked into the reservoir is equal to:

$$
\mathrm{Nc}=84 \times 135=11400 \text { ind. }
$$

The calculated additional amount of stocking with carp applies to the period of 2020. In order to enhance the stability level of the ichthyocenosis of the reservoir, it is necessary to form a stable breeding population of carp. In the future, it is permissible to withdraw no more than $50 \%$ of the grown individuals of industrial size (3-4 years). To comply with these regulations, stocking with carp fingerlings and one-year-olds in the calculated volume, that is, 11400 ind., or 8600 ind. of two-year-olds is necessary for 2020. With a commercial return rate of $20 \%$, the volume of additional fish products from one stocked generation will amount to 2270 ind. weighing at least $2.5 \mathrm{~kg}$, i.e. $5700 \mathrm{~kg}$. Starting from 2021, the annual stocking with carp is required in the amount of $50 \%$ of the primary one (2020), that is, 5700 ind. of fingerlings, or 4200 ind. of two-year-olds.

Thus, given the reserves of additional feed base and the need to maintain the ecological balance of the aquatic ecosystem of the Pershotravenske Reservoir, the volume of stocking by herbivorous fish and carp should consist of the calculated amount of stocking in total with the number of previously stocked fish (table 6). 


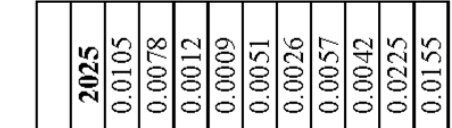

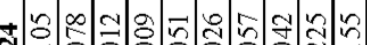

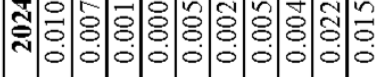

政

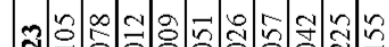

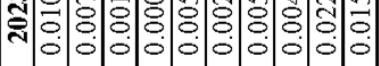

:

ㄴ.

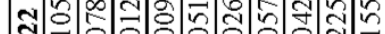

ิㅟㅇㅇㅇㅇㅇㅇㅇㅇㅇㅇำ

宩

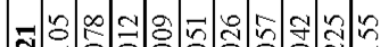

สิิ

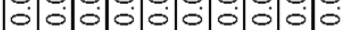

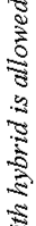

\%

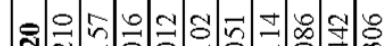

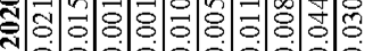

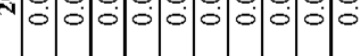

है

ํㅏㄴ- -00

Е

1010 ป

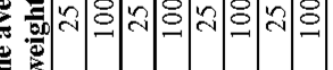

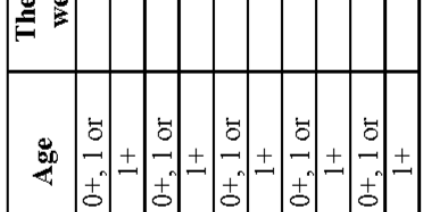

. 


\section{Permissible volumes of extraction of aquatic bioresources}

To preserve the biodiversity of the ichthyofauna and optimize the level of load on fish populations in the Pershotravenske Reservoir, the following volumes of annual permissible extraction of aquatic bioresources are recommended, by species (table 7).

Table 7

Permissible volumes of extraction of aquatic bioresources

\begin{tabular}{|c|c|c|c|c|c|c|c|}
\hline № & Species of fish & $\mathbf{2 0 2 0}$ & $\mathbf{2 0 2 1}$ & $\mathbf{2 0 2 2}$ & $\mathbf{2 0 2 3}$ & $\mathbf{2 0 2 4}$ & $\mathbf{2 0 2 5}$ \\
\hline 1 & $\begin{array}{c}\text { Silver carp + Bighead } \\
\text { carp (or hybrid) }\end{array}$ & 0.50 & 4.32 & 8.40 & 10.08 & 12.10 & 12.10 \\
\hline 2 & Grass carp & 0.00 & 0.77 & 0.92 & 1.10 & 1.32 & 1.32 \\
\hline 3 & Prussian carp & 2.30 & 2.99 & 3.89 & 5.05 & 6.57 & 6.57 \\
\hline 4 & Common carp & 0,06 & 1.42 & 1.42 & 1.70 & 2.04 & 2.04 \\
\hline 5 & Rudd & 0,10 & 0.10 & 0.10 & 0.10 & 0.10 & 0.10 \\
\hline 6 & Roach & 0.05 & 0.05 & 0.05 & 0.05 & 0.05 & 0.05 \\
\hline 7 & Tench & 0.05 & 0.05 & 0.05 & 0.05 & 0.05 & 0.05 \\
\hline 8 & European perch & 0.32 & 0.32 & 0.32 & 0.32 & 0.32 & 0.32 \\
\hline 9 & Northern pike & 0.05 & 0.05 & 0.05 & 0.05 & 0.05 & 0.05 \\
\hline 10 & Freshwater bream & 0.96 & 0.96 & 0.96 & 0.96 & 0.96 & 0.96 \\
\hline 11 & Wels catfish & 0.06 & 0.06 & 0.06 & 0.06 & 0.06 & 0.06 \\
\hline & Total & 4.45 & 11.09 & 16.22 & 19.52 & 23.62 & 23.62 \\
\hline & $\begin{array}{c}\text { Fish productivity, } \\
\text { kg/ha }\end{array}$ & 29.6 & 73.7 & 107.8 & 129.8 & 157.0 & 157.0 \\
\hline
\end{tabular}

Thus, the comprehensive implementation of stocking measures will increase the fishing capacity to $157 \mathrm{~kg} / \mathrm{ha}$, which is a relatively high indicator for reservoirs of this type, taking into account certain restrictions on economic activity due to the presence of species with special conservation status.

Commercial products will be caught using a standard set of fishing gear for plain reservoirs:

Fish stakes with a bar of $42-50 \mathrm{~mm}-60$ pcs; $70-98 \mathrm{~mm}-40 \mathrm{pcs} ; 100$ $150 \mathrm{~mm}-60$ pcs. Net length is no more than $35 \mathrm{~mm}$, height is $1.0-3.0 \mathrm{~m}$.

Shore seines with a bar of at least: $36 \mathrm{~mm}$ in the bunt, $40 \mathrm{~mm}$ in lead, $50 \mathrm{~mm}$ in wings; length is no more than $300 \mathrm{~m}$, height is no more than $4.0 \mathrm{M}-1 \mathrm{pc}$.

Trap nets with a bar in a barrel of at least $40 \mathrm{~mm}$, with wing length no more than $30 \mathrm{~m}$, and height of up to $3.0 \mathrm{~m}$, number of barrels no more than 2-4 pcs.

To take into account the specifics of environmental and economic aspects of the normal functioning of a special commercial fish farm, 
restrictions on the bar size are specified for the protection of Crucian carp and the implementation of specialized fishing for objects of artificial breeding and adventitious species, the Prussian carp.

Within the framework of the generally accepted concept of fishing use of herbivorous fish, under cc. 14.1.5. of Rules of commercial fishing in fisheries water bodies of Ukraine, which are approved by the Order of the State Agency of Fisheries of Ukraine No. 33 dated 18.03.99 registered with the Ministry of Justice of Ukraine on May 25, 1999, No. 326/3619 (hereinafter - the Rules of commercial fishing), it is advisable to provide the capture of older age groups of herbivores and other fish species with fish stakes with $\mathrm{a}=100 \mathrm{~mm}$ and larger in the amount of 30 pcs. Besides, for efficient (in particular, in regards to the optimal distribution of industrial load by size and weight groups) utilization of the Prussian carp stock, following c. 14.1.1. of the Rules of commercial fishing, it is advisable to use fish stakes with a bar of $a=42-50 \mathrm{~mm}$.

\section{Radioecological assessment}

Fish in aquatic ecosystems belong to the highest trophic levels and are directly connected to humans by food chains, so they are subjected to many radioecological studies. Contamination of fish with radioactive substances occurs through their intake with food objects, as well as due to direct adsorption by the body surface and as a result of other metabolic processes between the body and the environment.

Radionuclides were determined using the SEG-001 "AKP-S" gamma radiation scintillation spectrometer and the SEB-01-150 beta radiation spectrometer. The activity of radionuclides was calculated in $\mathrm{Bq} / \mathrm{kg}$ of raw mass.

In the water of the Pershotravenske Reservoir, the content of radionuclides is very insignificant: Cesium $-0.03 \mathrm{~Bq} / \mathrm{l}$, Strontium $-0.05 \mathrm{~Bq} / \mathrm{l}$.

In order to assess the levels of radionuclide accumulation in the muscle tissue of the main commercial fish species, the following fish were selected: carp, bream, roach, silver carp, catfish, pike, perch, rudd, Prussian carp (Table 8). These species are involved in the main trophic links, which makes it possible to assess the content of radionuclides in fish organisms with different food spectra, selected at different points of the reservoir.

Studies have revealed that the levels of ${ }^{137} \mathrm{Cs}$ in fish ranged from 0.32 in silver carp to $14.43 \mathrm{~Bq} / \mathrm{kg}$ in Prussian carp. The ${ }^{90} \mathrm{Sr}$ content in fish ranged from $0.11 \mathrm{~Bq} / \mathrm{kg}$ in silver carp to $7.13 \mathrm{~Bq} / \mathrm{kg}$ in catfish. Additionally, the high content of artificial radionuclides was detected in predatory fish. 
Table 8

Radionuclide content in fish of the Pershotravenske Reservoir

\begin{tabular}{|c|c|c|c|c|c|}
\hline \multirow{2}{*}{$\begin{array}{c}\text { Species } \\
\text { of fish }\end{array}$} & \multicolumn{5}{|c|}{ The content of radionuclides, Bq/ kg } \\
\cline { 2 - 6 } & ${ }^{137} \mathbf{C s}$ & ${ }^{90} \mathbf{S r}$ & ${ }^{40} \mathbf{K}$ & ${ }^{226} \mathbf{R a}$ & ${ }^{232} \mathbf{T h}$ \\
\hline $\begin{array}{c}{ }^{20} \mathbf{m} 0 n \\
\text { carp }\end{array}$ & $4.22 \pm 0.78$ & $2.45 \pm 0.92$ & $81.59 \pm 7.32$ & $32.01 \pm 5.36$ & $12.98 \pm 2.43$ \\
\hline $\begin{array}{c}\text { Freshwater } \\
\text { bream }\end{array}$ & $6.35 \pm 1.31$ & $3.42 \pm 0.77$ & $103.31 \pm 12.58$ & $25.12 \pm 5.13$ & $12.72 \pm 2.21$ \\
\hline Roach & $7.93 \pm 1.41$ & $2.44 \pm 0.12$ & $143.00 \pm 12.14$ & $33.42 \pm 7.43$ & $15.40 \pm 4.23$ \\
\hline Silver carp & $0.32 \pm 0.02$ & $0.11 \pm 0.01$ & $13.43 \pm 0.13$ & $3.59 \pm 0.02$ & $6.49 \pm 0.12$ \\
\hline $\begin{array}{c}\text { Wels } \\
\text { catfish }\end{array}$ & $9.40 \pm 1.56$ & $7.13 \pm 1.63$ & $94.01 \pm 2.34$ & $23.45 \pm 3.24$ & $15.80 \pm 3.24$ \\
\hline $\begin{array}{c}\text { Northern } \\
\text { pike }\end{array}$ & $10.13 \pm 2.16$ & $2.23 \pm 0.76$ & $17.53 \pm 3.25$ & $4.67 \pm 1.32$ & $11.50 \pm 2.11$ \\
\hline $\begin{array}{c}\text { European } \\
\text { perch }\end{array}$ & $7.34 \pm 1.42$ & $2.83 \pm 0.48$ & $87.43 \pm 5.43$ & $22.03 \pm 2.35$ & $8.05 \pm 1.91$ \\
\hline Rudd & $9.01 \pm 1.64$ & $2.19 \pm 0.44$ & $87.74 \pm 4.76$ & $21.83 \pm 2.22$ & $12.35 \pm 1.69$ \\
\hline $\begin{array}{c}\text { Prussian } \\
\text { carp }\end{array}$ & $14.43 \pm 2.54$ & $5.81 \pm 0.85$ & $167.00 \pm 12.73$ & $49.20 \pm 4.22$ & $42.31 \pm 4.15$ \\
\hline
\end{tabular}

Generally, the dynamics of accumulation of artificial radionuclides follows the scheme: euryphagous- predator - bentophagous - phytophagous. This is associated with bioaccumulation and biomagnification of radionuclides along the food chain. The highest content of artificial radionuclides was observed in euriphagous fish (Prussian carp), which is due to a fairly large and diverse food base (aquatic vegetation, zooplankton, zooand phytobenthos, other small organisms) and, in turn, large variability in the content of radionuclides in feed components. It is also contributed by the fact that Prussian carp is a bottom fish, since bottom sediments accumulate a significant amount of radionuclides, and while searching for food, Prussian carp exhausts the upper layers of bottom sediments, which leads to the transition of radionuclides from the accumulated state to the suspension one. The maximum content of radionuclides is observed in the upper $(2.5 \mathrm{~cm})$ layer of bottom sediments. Less content of artificial radionuclides was observed in the organisms of predators, however, it was still relatively high. Predators are the final link in the food chain, and radionuclides of previous links accumulate in the next ones. However, predators do not absorb the part of the radionuclides that were accumulated by the bone tissue of the prey, because it is low-nutritious and not fully digested. The lowest radionuclide content was observed in the silver car. This is due to the shortest food chain: phytoplankton - silver carp. 
Thus, the content of the studied radionuclides in fish of the Pershotravenske Reservoir did not exceed the standard indicators for fish as a food product, but fishing in potentially radioactively contaminated areas requires constant monitoring of the radionuclides content in ecosystems to assess the intake of these radionuclides into the human body through fish products.

\section{Procedure for amateur and sport fishing}

The conditions of the water area of the Pershotravenske Reservoir, including a reserve of native ichthyofauna, are appropriate for organizing amateur and sport fishing. Amateur and sport fishing is carried out per the "Rules of amateur and sport fishing", approved by Order No. 19 of the State Committee for Fisheries of Ukraine dated 15.02.1999 (as amended), registered by the Ministry of Justice of Ukraine on 28.04.1999, No. 269/3562 (hereinafter Rules of amateur fishing) with the following main provisions.

1) Amateur and sport fishing is allowed in the water area of the Pershotravenske reservoir based on special use of aquatic bioresources, under the current legislation. The basis for carrying out amateur fishing for citizens is a special ticket (fishing card) of a standard form, approved and issued by the user. Individuals are not allowed to catch aquatic bioresources without tickets (except for the cases provided for in Clause 4).

2) Amateur and sport fishing from the shore is allowed throughout a year (except for spawning grounds during the spring-summer ban on fishing for aquatic bioresources). Fishing is carried out with fishing rods of all types and names and spinning rods with a total number of hooks for fishing: in places of free fishing -5 pcs., in places of paid fishing -10 pcs.

3) In winter (from ice formation to ice breakup), fishing for aquatic bioresources is allowed with winter fishing rods with vertical baiting with a hook of no more than No. 10, with bait and live tackle with a total number of hooks of no more than 5 (five) per fisherman.

4) A section of the right bank starting from the 500-meter forbidden zone from the dam for $300 \mathrm{~m}$ upstream is allocated for free amateur fishing from the shore.

The right for free capture of aquatic bioresources throughout the entire water area of the reservoir is granted to (if there is an appropriate document):

- people with disabilities of Groups 1 and 2;

- participants in wars and armed conflicts;

- participants in the liquidation of the Chernobyl accident of categories 1 and 2, with fishing rods of all types with a total number of hooks no more than 5 per fisherman and one spinning rod. 
5) The allowed volume of the capture of native aquatic bioresources for one fisherman per day of stay on the reservoir is the following: fish $-5 \mathrm{~kg}$, crayfish - 30 pcs. The amount of extraction of introduced aquatic bioresources (carp, grass carp, silver carp) and a separate fee for their extraction is determined by the user. The annual volume of the catch of all types of fish by amateur fishing should not exceed $50 \%$ of the total volume of commercial catch for these species.

6) The amount allowed for fishing is established by the Rules of amateur fishing. Additional catch of individuals with body sizes smaller than allowed are to be returned to the reservoir in a live state.

7) The use of live bait on fishing gear is allowed from among those types of fish for which there is no industrial measure (c.10). Fishing of live bait is allowed with the use of dip net with a diameter of no more than $70 \mathrm{~cm}$ or lift nets with the size of $1 \times 1 \mathrm{~m}$ with a mesh of no more than $10 \mathrm{~mm}$.

8) Permissible load on the fixed area:

- summer period, fishing from the shore: no more than 1 fisherman per $10 \mathrm{~m}$ of coastline and no more than 50 people per the entire reservoir during the day; fishing from a boat: no more than 10 boats per day. Winter period: no more than 25 fishermen per 1 ha and no more than 50 people per the entire reservoir during the day.

An angler who extracts aquatic bioresources in the water area of the Pershotravenske Reservoir are obliged to:

- comply with the Rules of amateur and sport fishing in force on the territory of Ukraine;

- maintain proper sanitary condition in the water area of the site and the coastal protection zone, do not leave garbage, toxic substances and pollutants on the banks of reservoirs, in water and on ice, do not contaminate the site;

- have the relevant documents confirming the right to the special use of aquatic bioresources: a special ticket (fishing card) of a standard form, approved and issued by the user of the water body (except for the cases provided for in Clause 4 of this section);

- inform the user's Security Service about the facts of illegal fishing, other facts of illegal actions on the part of citizens and organizations, as well as the facts of detected fish deaths.

\section{It is prohibited for anglers to:}

- capture aquatic bioresources with the use of explosive and toxic substances, electric current, piercing fishing gear, firearms and air weapons (except for harpoon guns for spearfishing), industrial and other fishing tools made of mesh materials of all types and names, as well as use a means of gaffing; construction of small bridges and dams; 
- capture aquatic bioresources, carry out economic and other works on spawning grounds during the spawning period of fish, including the movement of boats, powerboats, except for security measures;

- export of aquatic bioresources over the established daily norm, taking into account the number of days spent on the reservoir. Exception: export over the established norm is allowed if the weight of one fish exceeds the average daily norm;

- catch crayfish during the spawning period, during molting and bearing eggs, which is established annually by the fish protection authorities, as well as in the dark with the use of lighting.

Per the current legislation, control over compliance with the Rules of amateur and sport fishing in the allocated area is carried out by the fishery protection bodies and the Security Service of water body user.

\section{Environmental protection measures to prevent deterioration of the ecological state}

The pattern for protection of the population of Crucian carp includes the following measures.

1) Limiting the mesh size. Due to the impossibility of conducting research directly on Crucian carp, we used data for a similar species (Prussian carp). For this purpose, data on the actual size and weight structure of Prussian carp catch in nets with different mesh size were analyzed. The results are summarized in Table 9.

Table 9

Indicators of Prussian carp in the catches of fish stacks

\begin{tabular}{|c|c|c|c|c|c|}
\hline \multirow{2}{*}{ Indicators } & \multicolumn{5}{|c|}{ Mesh size, $\mathbf{~ m m}$} \\
\cline { 2 - 6 } & $\mathbf{3 0}$ & $\mathbf{3 6}$ & $\mathbf{4 0}$ & $\mathbf{4 5}$ & $\mathbf{5 0}$ \\
\hline Average weight, g & 205 & 261 & 297 & 335 & 573 \\
\hline Average length, cm & 18.9 & 19.2 & 21.4 & 23.8 & 26.1 \\
\hline
\end{tabular}

Thus, given that the mode of the variational series of this species falls on individuals weighing $210 \mathrm{~g}$, nets with a mesh size of $40 \mathrm{~mm}$ or less are characterized by a fairly high catchability concerning this species. However, the older age groups of Crucian carp in this reservoir are small (according to previous studies, individuals over the age of 6 years in the reservoir were not observed); that is, the population of this species is sufficiently out of the influence of nets with a mesh size of $a=42-50 \mathrm{~mm}$.

2) Prevention of additional catch. This measure will be implemented in the generally accepted pattern for reservoirs: when registering individuals of Crucian carp in catches of nets, they are placed to other areas or replaced 
with gear with a large mesh size; fishing with active and trap gear allows returning additional catch alive; however, its implementation in areas of clusters of Crucian carp is prohibited. In any case, all additional catch of Crucian carp (regardless of the physiological state) should be returned to the reservoir.

Other measures to protect aquatic bioresources and increase fish productivity during the regime include:

- setting the permissible catch volumes at the level that is most saving for native ichthyofauna;

- stocking the reservoir with the establishment of the optimal limit for the use of the feed base;

- determination of spawning grounds and wintering pits and establishment of periods of the prohibition on fishing for aquatic bioresources;

- arrangement of artificial spawning grounds in the amount of 200 nests per year.

Given that the presence of significant depths (compared to adjacent areas) is the main criterion for choosing wintering grounds for most representatives of freshwater commercial ichthyofauna, the location of the main wintering pit of this reservoir is an area near the dam at a distance of $0.3 \mathrm{~km}$ from the dam, bounded by a dam and a gate with geographical coordinates: $48^{\circ} 35^{\prime} 44.70^{\prime \prime} \mathrm{N} 34^{\circ} 16^{\prime} 32.44^{\prime \prime} \mathrm{E}$; 48 35'41.13”N 34¹6'43.04'"E; $48^{\circ} 35^{\prime} 37.53^{\prime \prime} \mathrm{N} 34^{\circ} 16^{\prime} 53.06^{\prime \prime} \mathrm{E}$.

The area of the wintering pit is 14.2 hectares, or $9.4 \%$ of the total area of the reservoir, which is sufficient for ensuring normal wintering conditions for aquatic bioresources.

The results of the survey of coastal biotopes have shown that the main areas of reproduction and feeding of juveniles of most representatives of the native ichthyofauna of this reservoir are shallow, moderately overgrown areas of the upper part of the reservoir. Accordingly, the following area can be defined as spawning grounds the upper part of the reservoir from the confluence of the Samotkan River for $0.4 \mathrm{~km}$ downstream, bounded by a gate with coordinates: $48^{\circ} 35^{\prime} 20.54^{\prime \prime} \mathrm{N} \quad 34^{\circ} 16^{\prime} 18.82^{\prime \prime} \mathrm{E}$; $48^{\circ} 35^{\prime} 17.72^{\prime \prime} \mathrm{N}$ $34^{\circ} 16^{\prime} 28.46^{\prime \prime} \mathrm{E}$; $48^{\circ} 35^{\prime} 15.24^{\prime \prime} \mathrm{N} 34^{\circ} 16^{\prime} 36.96^{\prime \prime} \mathrm{E}$.

The area of spawning grounds is 22.3 hectares, or $14.8 \%$ of the total area of the water mirror, which is sufficient for forming a spawning fund for native species.

The terms and areas of the ban on fishing for aquatic bioresources are established by orders of the territorial fishery protection body following the Rules of commercial fishing and the Rules of amateur fishing. 
Stocking should be carried out following the "Procedure for artificial breeding (reproduction), cultivation of aquatic bioresources and their use", approved by Order No. 414 of the Ministry of Agrarian Policy and Food of Ukraine dated 07.07.2012, registered by the Ministry of Justice of Ukraine on 27.07.12 No. 1270/21582.

Reporting on the volume of the special use of aquatic bioresources is provided to the territorial body of the State Agency of Fisheries by species, monthly by the 5 th day of the month following the reporting month.

Protection of aquatic bioresources is carried out by the user.

The user must comply with the requirements of the instruction "About the procedure of artificial cultivation, cultivation of fish, other water live resources and their uses in special commodity fisheries", approved by the Order of the State Committee of Fisheries of Ukraine dated 15.01.2008 No. 4, registered by the Ministry of Justice of Ukraine on 28.01.2008, No. 64/14755 and the Regime.

\section{CONCLUSIONS}

Thus, the conducted comprehensive studies of the Pershotravensk reservoir make it possible to use it for fisheries purposes. In case all these recommendations are followed for the next 5 years (2021-2025), the fish productivity of the reservoir may increase from $73.7 \mathrm{~kg} / \mathrm{ha}$ to $157.0 \mathrm{~kg} / \mathrm{ha}$, which on average will allow withdrawing from 11 to 23 tons of high-quality fish products grown in pasture aquaculture on a natural feed base.

\section{SUMMARY}

The chapter presents the results of the comprehensive hydrobiological and ichthyological studies dedicated to the Pershotravenske Reservoir, conducted in 2019. The paper presents modern materials about the hydrochemical condition of the reservoir; the current hydroecological state of the reservoir and its potential use for the development of fisheries in the region are described.

The characteristics of the biological productivity of the forage base of the reservoir (phytoplankton, zooplankton, benthos productivity) have been determined. The results of the assessment of the feed base have revealed that the reservoir has a significant fishery potential. It has been determined that the species composition of ichthyofauna is depleted and can be used for pasture aquaculture and fisheries development. The paper presents calculations of fish productivity in the reservoir and recommended volumes of stocking with fish for long-term fisheries use of the reservoir. The paper provides recommendations for rational commercial fishing in the reservoir.

It has been found that the reservoir is inhabited by the Crucian carp, which is listed in the Red Book of Ukraine. Therefore, the recommendations 
for commercial fishing contain certain restrictions to preserve the population of Crucian carp. Compliance with the provided recommendations will allow obtaining 11 to 23 tons of high-quality fish products annually.

Since the reservoir is located in a region with a potential radiation hazard, the paper presents data on the assessment of the quality of fish products in terms of the content of natural and artificial radionuclides in industrial fish species. It has been found that the levels of radionuclide contamination do not exceed the established standards, and fish from the reservoir may be recommended for consumption.

\section{REFERENCES}

1. Про рибне господарство, промислове рибальство та охорону водних біоресурсів : Закон України № 3677-VI. Відомості Верховної Ради України. 2012. № 17. Ст. 155.

2. Про тваринний світ : Закон України № 2894-III. Ст. 37. Відомості Верховної Ради (ВВР). 2002. № 14. Ст. 97.

3. Інструкція про порядок здійснення штучного розведення, вирощування риби, інших водних живих ресурсів та їх використання в спеціальних товарних рибних господарствах : Наказ Державного комітету рибного господарства України від 15 січня 2008 р. № 4.

4. Озінковська С.П., Єрко В.М., Коханова Г.Д., Тарасова О.М., Полторацька В.I. Методика збору i обробки іхтіологічних i гідробіологічних матеріалів 3 метою визначення лімітів промислового вилучення риб з великих водосховищ і лиманів України. Київ : IPГ УААН, 1998. $47 \mathrm{c}$.

5. Методические рекомендации по сбору и обработке материалов при гидробиологических исследованиях. Зоопланктон и его продукция. Ленинград : ЗИН, 1984. 35 с.

6. Методи гідроекологічних досліджень поверхневих вод / за ред. В.Д. Романенко. Київ, 2006. 628 с.

7. Щербак В.I. Методи досліджень фітопланктону. Методичні основи гідробіологічних досліджень водних екосистем. Київ, 2002. C. $41-48$.

8. Гринь В.Г. Об'ємно-вагова характеристика провідних видів фітопланктону Нижнього Дніпра. Питання екології $і$ иенології водних організмів Дніпра АН УССР. Київ, 1963. С. 35-40.

9. Жадин В.И. Методика изучения донной фауны водоемов и экология донных беспозвоночных. Жизнь пресных вод СССР. Москва : Наука, 1956. Т. 4. Ч. 1. С. 279-382.

10. Гринжевський М.В. Аквакультура України. Львів, 1999. 202 с.

11. Baker J.P., Olem H., Creager C.S., Marcus M.D., Parkhurst B.R. Fish and Fisheries Management in Lakes and Reservoirs, EPA 841-R-93-002, 
Terrene Institute and US Environmental Protection Agency, Washington, DC, USA, 1993.

12. Avakyan A.B., Iakovleva V.B. Status of Global Reservoirs: the Position in the Late Twentieth Century. Lakes and Reservoirs: Research and Management. 1998. Vol. 3. P. 45-52.

13. Шерман И.М. Экология и технология рыбоводства в малых водохранилищах. Киев : Высшая школа, 1992. 213 с.

14. Пидгайко М.Л. Потенциальная продукция. Методы определения продукции водных животных. Минск, 1968.

Information about the authors:

Marenkov O. M.,

Candidate of Biological Sciences, Associate Professor, Head of the Department of General Biology and Water Bioresources

Oles Honchar Dnipro National University 72, Gagarin avenue, Dnipro, 49050, Ukraine

Izhboldina O. O.,

Candidate of Agricultural Sciences, Associate Professor at the Department of Livestock Production Technology Dnipro State Agrarian and Economic University 5, Voroshylova str., Dnipro, 49027, Ukraine 